Historic, Archive Document

Do not assume content reflects current scientific knowledge, policies, or practices. 
1. 
in $\quad$ REK. 1901

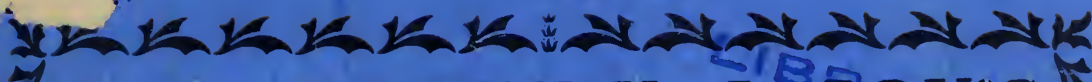
(J.R. RATEKIN \& SON'S

7 . 11 ilLustrated NOV 24197

r Fatalog

$\pi$

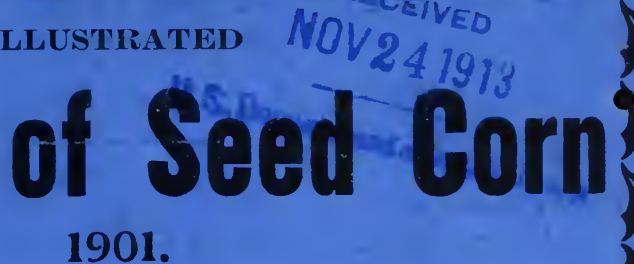

ESTABIISHFD IN 1884.

$\pi$

$\lambda$

$\pi$

7

7

$\$$

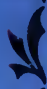

$\checkmark$

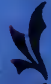

t)

4

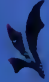

$y$

$\pi$

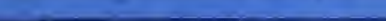


Thos. H. Read, Prest. $\quad$ E. A. Read, Cashier. J. F. Lake, Ass't. Cash

\section{THE FIRST NATIONAL BANK, SHENANDOAH, IOWA.}

\section{CAPITAL AND SURPLUS $\$ 100,000$}

To Whom it may concern:

SHENANDOAH, IOWA, DEC. 11899.

This, is to introduce to your favorable notice Messrs. J. R. Ratekin \& Son of this place.

Mr. Ratekin, Sr., has been a valued customer of this bank for many years, and has always been esteemed by us as a reliable and trustworthy man in every respect.

He has now associated with himself in business, his son, J. W. Ratekin, who is an active, energetic, and worthy young man, and we bespeak for the new firm a large share of confidence and patronage of the business public.

Respectfully,

T. H. READ, Pres. First Nat. Bank.

\section{Omaha \& Saint Louis Railroad,} Shenandoah Station.

SHENANDOAH, IA. JAN. 3, 1901.

To Whom this may concern:

I take pleasure in saying that I am personally acquainted with the members of the seed firm of J. R. Ratekin $\&$ Son, the senior member having made the growing, handling and shipping of seed corn a specialty here for the past sixteen or seventeen years, and they have been among the largest shippers in recent years over the Wabash Rallroad, also the Omaha Kansas City and Eastern, "Quincy Route," each of which I have been associated with as agent at this place. Indeed during the past year or two this firm has made more single shipments from this point over these roads, than any firm or business house many times multiplied. During all their years in the seed trade here, I have never heard a complaint from any patron or customer of theirs from any cause, and I have no hesitation in saying that $I$ believe them to be gentlemen of integrity, and any one having business transactions with them may feel assured of fair and honerable treatment.

Respectfully, H. C. BEDison.

\section{What the Postmaster of Shenan- doah Says:}

U. S. Postoffice.

Shena dDOAH, IA., JAN. 3, 1901. To Whom it may concern:

I take pleasure in saying I have known Messrs. Ratekin \& Son, of this place, for many years and can recommend them as trustworthy, energetic business men. Mr. J. R. Ratekin, senior member of this firm, has been engaged in the seed corn business here for many years and has sold and shipped large quantities of seed corn to all parts of the corn growing country, including many different states, and I have never heard any complaint from any customer.

Respectfully submitted, C. N. Marvin, Postmaster.

Office of C. M. Conway, Groceries, Provisions and everything to be found in a first class Grocery Store.-Shenandoah, Iowa, Jan. 1, 1901.

To whom this may concern:

This is to certify that I am well acquainted with the seed firm of J. R. Ratekin \& Son of this city, and take pleasure in recommending them to the public, as being reliable and trustworthy. C. M. CoNwAY, Mayor, Shenandoah, Iowa. 


\section{To Our Friends and Patrons}

We wish here in the first paragraph of our "book" and seed catalog for 1901 to publicly express our true and sincere thanks to you, kind friend and patron, not only fur the patronage you have given us in the past, but also for the interest you have manifested in calling the attention of neighbors and friends to our seeds and speaking a good word to them for us. In this way you have materially increased our sales in your neighborhood and among your friends. often extending far and wide, thus to you and this measure of kindness is due laryely our increased business from a small start in I884 that has grown t., be as great. if not the greatest, in the line of our specialty, the growing of SEED CORN, to be found in the United States. We shall take the same, and every puins in the future to maintain that confidence and friendship gained through honest and fair dealing with each and all, including old and new friends, customers and patrons, that has ever characterized our course in the past.

Our SFED CORN trade and business, more especially for the past year and season, was next to enormous, so much so that we have have been obliged to materially increase our facilities all along the line and on every hand. Early last year we laid out our plans for this and future year's business, and begun by planting something over 1200 acres of corn, seed grown, cured and prepared especially for our own purposes to grow this stock. It was all planted very early, and practically all of it on new sod ground, ground that had been in pasture and clover fields for a number of years, then plowed up for this season's crop. In thus combining superior varieties, good seed, good ground and good cultivation we obtained a good stand, rapid growth, early maturity and seed of great vitality and germinating power; therefore we are in a position to offer direc: to the furmers and corn growers of the United States stock and seed such as cannot be excelled, if equaled, by any seed house or seed corn growers in the world, and we feel contident in offering this seed that the results to be obtained from planting it will be not only highly satisfactory to all but profitable as well to the farmer who plants it.

While our seed crop was growing the past season and almost before closing up last season's seed business, we began other enlargements in the way of new grounds, buildings, drying houses, boiler and engine for turing our shellers, cleaners, fanning mills, etc., etc., and for heating and drying throughout our plant, and have just finished one of the most complete as well as largest plants of its kind to be found in the world, the main building being two stories high, $64 \times 124$ feet, besides other additional facilities for storing twenty-five thousand bushels of seed corn, making our capacity, in all, abuut 75100 bushels for the trade for the season of 1901 .

\section{A Few Words About Ordering}

Our business and trade is direct with the farmer and corn grower, who can order as easily, buy as cheaply, get the sane freight rate any one else can, and we assure all who favor us with their orders, the $t$ they shall have our prompt personal attention, and the seed will be shipped as directed and on same day order is received.

GUARANTEE. We exercise the greatest care in the selection of our seed and send out nothing but pure varieties and of the strongest vitality, and if any seed received from us is not fully satisfactory on receipt and examination, it may be returned at our expense and money paid for it will be refunded, but we give no warranty, expressed or implied, and will in no way be responsible for the crop. 


\section{Directions for Ordering}

OUR TERMS ARE STRICTLY CA SH WITH ORDER. We do not send C. O. D. as cost and inconvenience to you for collection and return charges is an unnecessary item of expense, besides it would require too much time and help and cause delay of shipment while we obtained the standing of those who order that way. As to our responsib lity see inside first cover page for references.

HOIV TO SEND MONEY. Remit tances mav be made at our risk by any of the following methods, viz: Pistotfice Money Order, Bank Draft, Express Money Order, Registered Letter, and in sums of $\$ 1$ and less in postage stamps.

The rates for Postofiice and Express Money Orders is now very low and these are the most convenient modes for sending money, consequently the best to most of our customers. Express Money Orders can be obtained at all express oftices and from all ag nts of different companies everywhere. All these ways of remitting are absolutely safe and at our risk.

SHIPPING. We are located on the C. B. \& Q Railway, Omaha, Kansas City, Quincy and Eastern Railway and also on the Omaha \& St. Louis line of the Wabash Railway, and on the Humeston \& Shenandoah Railroad, this place being the western terminus.

Use our blank order sheets when crinvenient and you have them. Always be sure to write your name plainly, also your postoffice address, county and state. I) n't think becanse you are familiar with all of them that everybody else is. Therefore don't write them in a careless manner.

be sure to give the name of your freight station, also name or names of railroads.

FIRIGHT RATES AND CHARGES. We advise our customers to order early and have their seed sent by freight always, as it costs four times as much by express, as by freight. We liave excellent railroad shipping facilities, and direct connections at Omaha, Cuuncil Bluffs, Des Moines, Ottumwa, Burlington. Davenport, R Quincy, St. Lou's and Kansas City, besides inuumerable junctions and crossiugs with trunk lines, and we generally reach most points in Iowa, Illinois and Nebraska, in two to four days; Missouri, Kansas, Michigan, Indiana and Wisconsin, in from two to six days; Ohio, Kentucky, Tennessee, Lourisiana, Texas. Oklahoma and Indian Territory in from four to ten days. In fact we are able to reach most any railroad point in the United States in ten days, as we have fast through freight arrangements to many points, and with a system of tracing, we can prevent unnecessary delays at transfer points, from one railroad to another, and thus materially lessen time in transit.

RUSH ORDERS. If time is limited and you wish to order seed of any kind by telegraph, go to your Banker, Express Agent or Postmaster and put up the money and have them wire us what you wish, and you may feel assured that your order will have immediate attention, and seed will start by first train. We know low to move without a derrick, and are in a position to give you prompt and rapid service.

\section{We are But Human,}

We take pride always in trying to be correct in all our shipments. However, we are but hum»n, and occaslonally make mistakes like other poor mortals, but when we make a mistake we want to remedy it. If in the course of business with us, you find an error or mistake on our part, please write us a letter with a plain statement of facts, and you may depend upon receiving honorable and pleasant treatment. D nn't get angry and come at us like a hog going to war. We pride ourselves on having a large warehouse full of patience, but are not indifferent to facts pleasantly stated, and separated from abuse. 


\section{"Quality Before Quantity."}

"The best is always the cheapest." Reliable seeds above all else, especially seed corn, gives and lays the foundation for a good and perfect crop. They cannot be produced nor sold at half price. Poor seed is dear at any price or even as a gift, and we do not attempt to crmpete on prices with grain dealers,common elevator corn and novices, without experience or conscience. Therefore we try to produce the best seed frem the best varieties and shall continue to make quality not quantity, paramount to all else, bolieving as a practical business proposition, that it is the best and largest return that gives the most satisfactory and profitable results for the money invested. We have made our prices as low as possible consistent with the care and preparation of high grade and reliable seed. Our prices are absolutely alike to all, and when you send to us for seed you have the satisfaction of knowing that no one gets seed for less than you do, from us.

More than fifty years practical experience on the farm as a corn raiser in one of the best corn growing sections under the sbining sun, seventeen of which have been devoted to the growing and handling of seed corn as a specialty, has given us a direct practical business experience with thousands of the best corn growing farmers all over the country, especially with those of the great corn growing belt of the Central, Wistern and Southwestern states, thus bringing and keeping us in close touch with the best, most practical and progressive farmas of the United S'ates, thereby deriving much beneficial knowledge from their experience. From these long years of experience we have found the ssential points must desired are seed that will grow, a pure variety of uniform good size, with no barren stalks, not of the overgrown Jumbo sort, but, with 16 to 24 rows, deep grin and as small cob as cons'stent to bear them, thus drying out eir'y and quickly, and combining all the ess ntial points to obt in the largest possible yield of the s undest, solidest aud best co $n$ in the shor est length of time.

Since 1884 when we first engaged in the growing and handing of seed corn as a specialty, our trade and business has gradually and steadi y increased year by jear, last year (1993) reaching the climax over any previous year, aggregating and reaching into the tens of thous inds of bushels, and nere perhaps greater than any like ins itution to be found in the world. In Iowa alone, our lome state, wher ; the record of the most corn and largest yield per acre was mide over any uther stato for 1900, as shown by governinent report, we received orders from and sent ssed iut's every county without exception, and to very many of them every railroad town and hamlet in them. To Illinois we like wise sent seed to every county within the borders of the state. From Missouri we received orders from 90 per cent of all the counties of the state, while we had orders in large numbers for large quantities from over 50 per cent. of all the counties of Nebraska and Kansas, and in all received orders from 38 different states, including a large trade and business from Kentucky, Tennessee, Georgia, Mississippi, Louisiana, Texas, Oklahoma and Indian Territory.

Smoking seed corn will do it no harm. It has a tendency to keep squirsquirrels from working on it. They do not dislike it altogether, but they will not dig it up as readily as they will corn that has not been smoked. 


\section{For "Old Kentucky,"}

Messi's J. R. Ratekin \& Son received orders this morning from the state of Kentucky alone for over four hundred bushels of their famous seed corn. Thus far this season they have received orders for and shipped in the aggregate several thousand bushels of seed to the blue grass state. Mr. Ratekin, senior, says he has always known that the true Kentuckian rode in the best of carriages, by the side of the prettiest women. drawn by the finest horses in the world, and now they are coming after their tine varieties of seed corn, "Pride of the Nisnha" and "Iowa Silver Mine" in palace cars, thus keeping up the pace and example set before the wo:ld. Messis Ratekin \& Son grow nor handle nothing but the finest and best quality of seeds and in this way and in knowing how to treat their patrons well, have built up a tremendous trade for their seeds among the best and most progressive farmers all over the Central and Western states. all of which they have richly merited and deserve. - Shenandoah World, April 6, 1900.

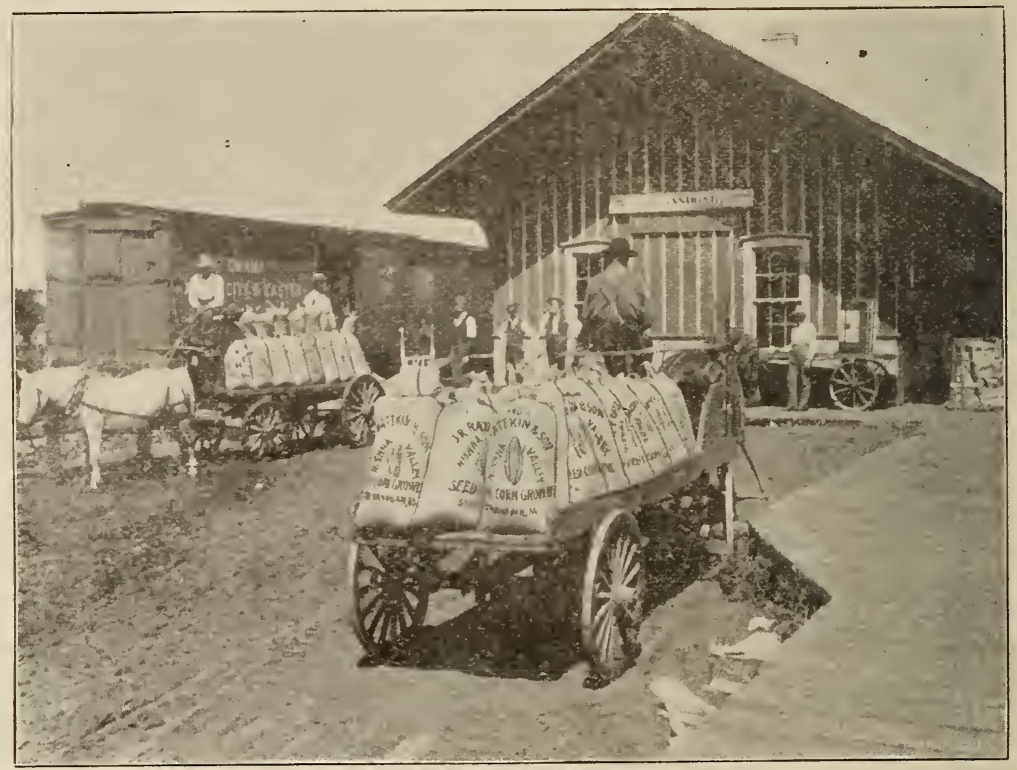

LOADING A CAR OF SEED CORN AT OMAHA \& ST. LOUIS DEPOT BY RATEKIN \& SON. APRIL 6. 1900. FOR KENTUCKY.

P. B. Pendleton, of Pembroke, Ky., one of the largest and most progressive farmers, breeders and shippers of thoroughbred I)urock Jersey Swine in Christian Co., Ky., inclosing his check for 75 bushels of our "turkish red" seed wheat, says: "The "Pride of Nishna" seed corn I obtained from you last spring is all right, its tine."

"What can't be cured must be endured." The farmer will say of his fields, "What can't be manured must be endured." 


\section{B. \& Q. Depot, Shenandoah, Iowa.}

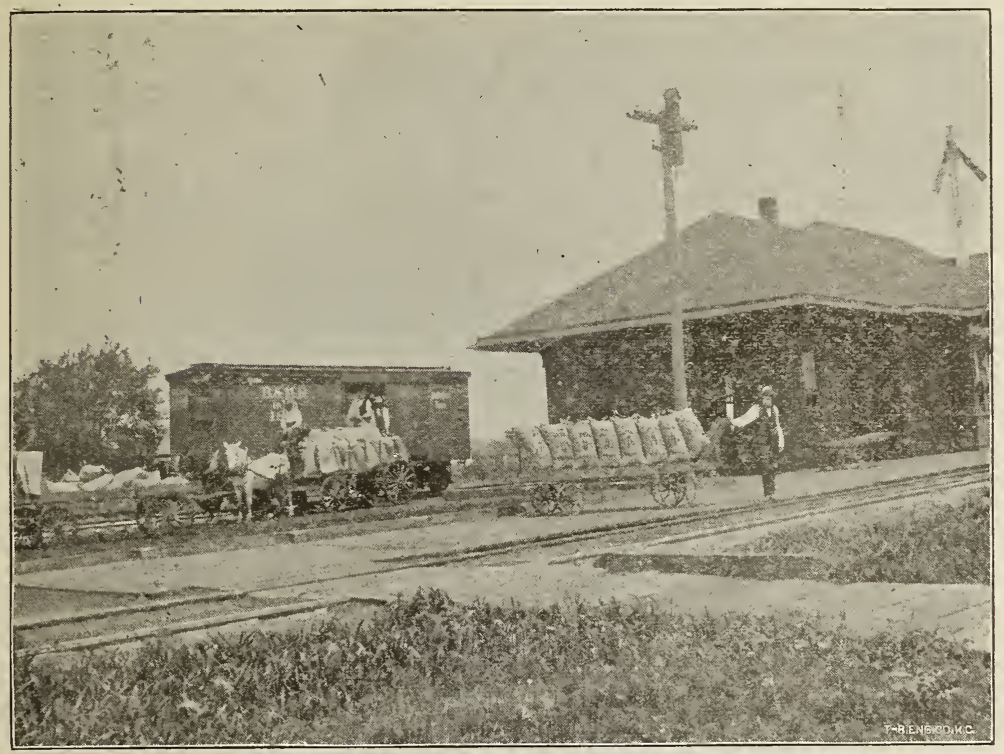

RATEKIN \& SON LOADING SEED CORN FOR IOWA AND ILLINOIS POINTS MAY 5, 1900.

As elsewhere stated, Shenandoah is located on the Red Oak and Lincoln line of the "Great" C. B. \& Q., "Burlington Route," 31 miles east of Nebraska City, and does a greater volume of business here than any other point in Iowa, except Burlington, Council Bluffs and Ottumwa, where the large wholesale business, combined with local traffic and conditions, makes them alone equal or more than from Shenandoah.

The "Burlington" is one, if not the greatest trunk lines that crosses the prairies of Iowa. The mileage being in all 8063 miles, locomotives 1600, passenger cars 1200 , freight cars 40,000 , daily trains 600 , cities and towns reached 1200 , states entered 11, passengers carried daily 20,000, passenger trains seperated the last year if hitched together would make a string 5859 miles long, freight trains and cars 30,000 miles. If all put together would reach once, and nearly a half, around the world. The gross earnings of the road is said to have been $\$ 50,000,000$, last year.

The American farmer feeds the world better than he feeds himself. Farmers ought to be the most prosperous people on earth, for they feed and clothe more people than any two nations in the world. They produce the stuff and the people of the earth must have it and pay good prices for it. In this country one man can grow food enough for a hundred persons. No other people in any age can or ever could do as much. One reason he is not better off is because he does not regulate prices for his products. Gamblers do that for him. 


\section{A Few Words About Ourselves and Business.}

Fifty-six years ago, 1844, I was born in Warren County, Illinois, where I grew to manhood. On the breaking out of the clvil war I enlisted in the 11th Illinois Cavalry, serving to the end of the war and was mustered out of service at Memphis, Tenn., in the fall of 1865. Two years later in $1867 \mathrm{I}$ left Illinois, settling here in Southwestern Iowa, on a farm near where the city of Shenanandoah is now located, although then a wild prairie where the deer and prairie wolf roved at will without molestation by man.

Having been born and reared on a farm I naturally took up the avocation of farmer, the business of all others most charming to me. Being located in
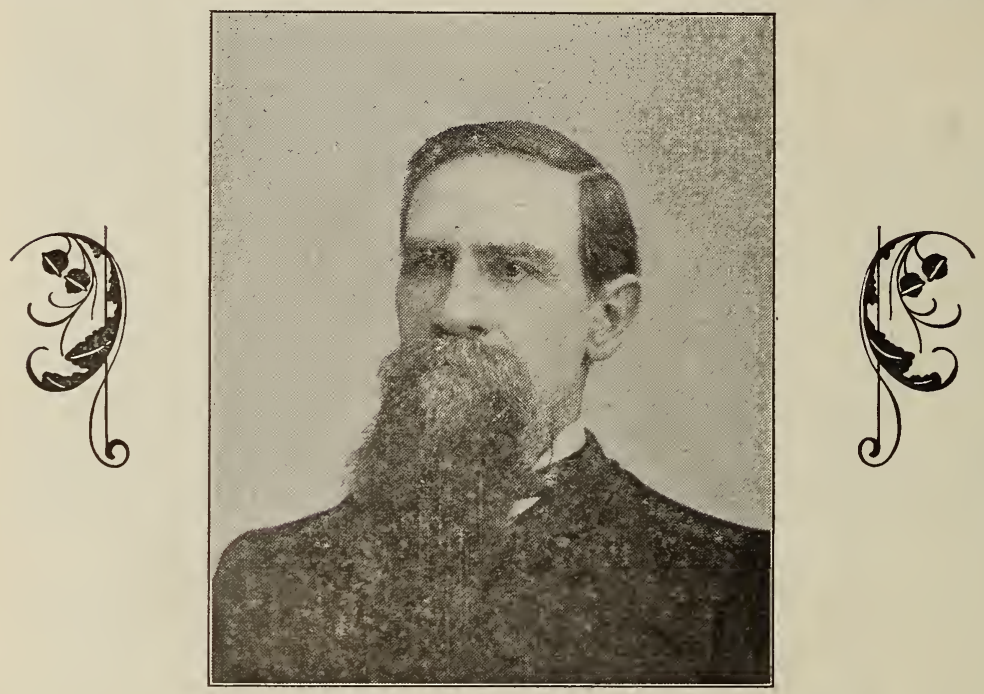

COMPLIMENTS OF J. R. RATEKIN.

the very heart of the best corn-growing country, both in Illinois and here in Iowa, as well, I have given, and made the growing of farm products, especially corn, my life long vocation, and during the past seventeen years have made the breeding, propogation and growing of seed corn a specialty.

\section{HOW I BEGAN.}

Long ago from practical experience as a corn grower I became convinced that most farmers could, through careful selection and planting only the best varieties of corn, almost, if not quite, double the product of their farms, and as it were, thus "make two blades of grass grow where but one grew before." Possessed of this conviction I spared no effort to obtain the very best, and most improved varieties of corn to be found. without regard to cost of seed, this being an absolute insignificent item in the cost, production of, and results to be obtained from a corn crop of 40,50, 100 or even 300 to 400 acres, which amount I have often grown. My ideal of the best and most profitable corn to be grown was a variety of good, large, medium size, deep grain and as small cob as consistent to carry 16 to 24 rows, well developed and carried out at both the butt and tip, that would mature soundly in the shortest given length of time. In 1884, in the early part of the year, it developed that there was a genuine seed corn famine on, extending all over the central and western states, and seed was being sought after very generally and commanded, in price, from $\$ L$ on up to $\$ 2.50$ per bushel, as it could be obtained for. At that time I had in crib and in store something over 5,000 bushels of just such corn as I have here described, and upon inspection and examination, found that 
almost every ear and every grain on it would grow. As soon as this became known, and it spread like wildfire, farmers, seedmen and corn growers from far and near began to draw on my cribs for their seed corn at $\$ 1.25$ per bushel, one customer alone taking 2400 bushels at $\$ 1.25$ per bushel, he furnishing the bags to put it in, delivered aboard the cars here at Shenandoah. Since that time, except nearly four years that I had charge of, and was commandant of the Iowa State Soldiers' Home, at Marshalltown, this state, I have given my undivided attention to the improvement, propagation and breeding of seed corn as a specialty, however, I meantime was appointed by the president and served as postmaster at Shenandoah four years and two months, but never for a moment relinquished the farm or my interests in the continued growing and breeding of corn for seed purposes.

J. R. RATEKIN.

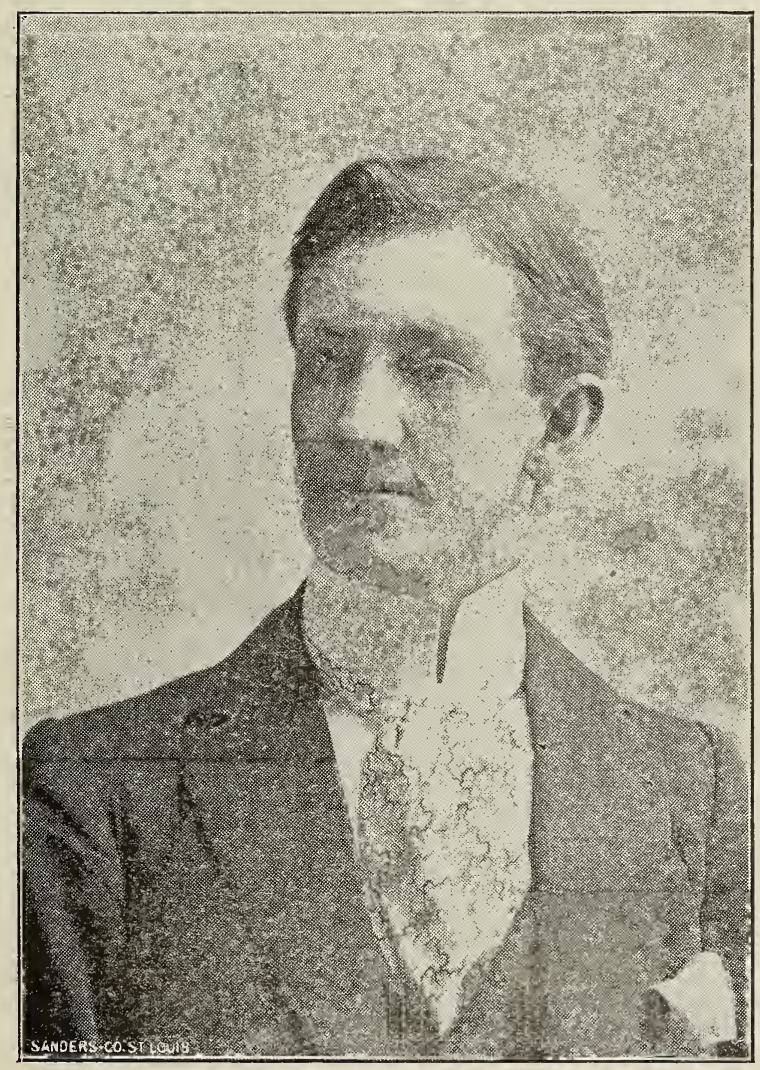

COMPLIMENTS OF J. W. RATEKIN.

NEW PLANT IN 1900.

In I899, my son, J. W. Ratekin, became associated with me in business which has contributed materially to the extension of our entire business and trade, as well as to more perfect efficiency in growing, handling and caring for our seed and seed business. During the present year, 1900, in addition to acreage planted and grown for seed, we have built anew one of the largest, if not the largest, seed corn and drying houses to be found in the country, add- 
ing whatever accompaniments, in the way of needful and suitable apportionments necessary, and such as practical experience in the past have indicated for the better handling, storing and putting up seed to meet the requirements of our trade.

In conclusion permit us to emphasize the fact that our trade and business has been built up and conducted strictly with the farmer, thus they have got their seed direct from the grower, and therefore know where it was grown and who grown by, and to know this when they get seed from, at least some seed houses, would require that they be either a prophet or a mind reader. In our business experience we have had scores of requests from seed houses to quote prices for large quantities, and at seasons, early and before the farmer trade began, have made prices on such quantities, at a figure that left almost absolutely no profit to us in order that we might give and keep our help employed until such time as our farmer trade begun, but in no instance, except one above mentioned have we ever been able to quote prices low enough to compete with common crib corn, bought up over the country, regardless of kind, sort, variety or quality, after which it was shoveled into the cars and shipped to these seed houses and given a big name, and then sent r ut at fabulous and extortionary prices.

We unquestionably have the best location, finest, live, deep, loam soil and most perfect seasons and climate for growing seed corn here in the "Nishna Valley" of Southwestern Iowa, to be found in the world, where all the conditions will permit of early planting and early maturity always attended with dry, pleasant weather up until near Christmas and sometimes much later. But in our experience this is not all the requirements to obtain the best high quality of seed corn. It requires the best pure varieties, the same as in breeds of stock. This should be propogated with a well defined purpose, planted for seed purposes and improved if possible from year to year. Then corn for seed should be handled and cured for seed purposes, thoroughly dried and kept dry. Most of our corn here will grow if properly cared for at picking time, but put into common corn cribs where it may become damp from snow, rain and various conditions of weather, while it may all be sed corn, or corn that would grow if tested today, a sharp, solid freeze of a day or two while damp, and not a grain in a thousand will grow. Its cooked, its done. Finally comes the selecting, sorting, nubbing and examining of $e^{\circ} \mathrm{ch}$ and every ear, and this can be done one way only, by hand, competent and trustworthy men, men of practical experience and that are experts in that line of business, and to insure this precaution must be used in the emp'oyment of competent inspector to see that all is well done. To do this properly requires time, and is among other things one of the important items in the business. On this point we plead gui ty to the charge of "crank" but believe we are no more cautious on this point than every practical farmer ougbt to be; for "on the seed depends the crop," "No seed no crop," "Poor seed poor crop," "but with good sefd half the crop is made to start with." We fully realize the ruinous effect of poor seed. The corn crop is the main deperdence. The preparation and growing of a corn crop consumes time and labor and can be grown but one time in the whole year. Some people quibble about ten cents on the price of a bushel of seed. This is economy at the spigget while the bung hole flows. The reduction of 10,20 or even $50 \mathrm{c}$. on a bushel of seed means but tl ree, fire or seven cents per acre for the seed it takes to plant it, a poor to halt crop means a loss of $\$ 3, \$ 5$ to $\$ 7$ per acre in flnal results. This is not a mathematical problem that requires a mathematician to solve. Figure it un for yourself. Respectfully, J. R. RATEKIN \& SON.

Don't trust to luck for he never pays a debt, his own or anybudy else's.

Plant your corn on your land, but do not forget to plant a rose in your garden.

A father maintains ten children better than ten children maintain one father.-German. 


\section{Our Gold Medals.}

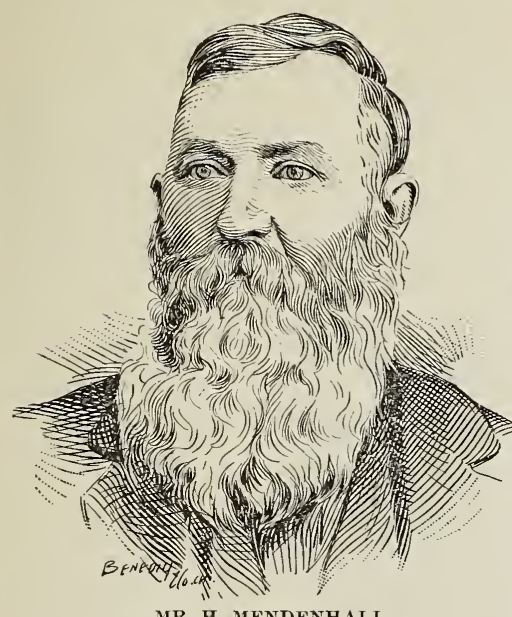

MR. H. MENDENHAI.L.

Office of H. Mendenhall, Mfgr. and Gen. Agt. of the Boss Pig Extractor. Audubon. Audubon Co., Ia., Nov, 1,1900

Messrs, J. R, Ratekin \& Son, Shenandoah, Iowa-Gentlemen:-I wrote you some time ago with regard to prospective results from the seed corn, "Pride of Nishna," obtained from you last spring. I write now to say I am harvesting and gathering the crop, and find it even better than then anticipated. It is yielding from 90 to 100 bushels per acre of the finest corn I ever grew. I must tell you about the premium I won at our county fair here this fall: There were a number of special prizes offered at our fair by some of our enterprising merchants and others, among them was one for the best and most perfect ear of corn produced by any farmer in this county, the premium being $\$ 16.00$, sufficient to stimulate sharp competition and lots of it: there being twenty-five contestants. Among them was myself with an ear of "Pride of Nishna" grown from the seed botained from you last spring. It was a model of perfection weighing $1 \frac{8}{4}$ lbs., 12 inches long, very deep kernel and small cob, like all of them are. The judges were all disinterested parties and did not know one farmer's corn from another's, therefore, could be no room for partiality or unfair judging, and you must know that it was gratifying to me when I was advised that my ear of "Pride of Nishna" had been awarded the prize. I paid you $\$ 9$ for 10 bushels of seed: obtained $\$ 16$ premium on one ear and will have from six to seven thousand bushels of corn left. How is that? Very respectfully,

\section{Selecting Seed Corn.}

For a number of years farmers have been advised to go through their corntields before gathering time and select the best ears for seed. I do not believe this will result in much improvement unless the non-productive stalks can be cut out before the pollen is distributed. If these inferior stalks fertilize the stalks which produce the large ears, much improvement is impossible. In my own case I plant a small plat with the hills 4 feet apart each way. I give good cultivation and when the tassel emerges from the stalk and before pollen is shed, I cut out every stalk that has less than two good ears. A few years of this kind of selection will result in a greatly increased yield. For this seed patch of corn I select ground as far away from other corn as possible. J. O. Mouson, Pennsylvania.

We notice that corn fields which were continually worked by the shallow or surface stirring method have made the best growth and withstood the dry weather. The "dust mulch" principle is certainly a feasible plan of overcoming the baneful effects of drouth.

Our Northwestern farmers are nearly alive to the great advantage of sowing good seed-that is proven by the quality of wheat they market-very few of them, however, are successful enough to have the seed thoroughly cleaned. Well matured and thoroughly clean seed, is as a rule, to be had so easily that there is no excuse for sowing weed seed or poor wheat.

Many a good farmer has been spoiled by making a politician out of him. 


\section{Seed Corn. Growing and Choosing Seed Corn.}

The following rule and guide is so eminently reasonable. logical and correct, and conforms so completely to our plan that we allow another to give it as his own, and most heartily commend it to all corn growing farmers - J. K. R. \& Son.

Line upon line is written every year upon this important subject, by men who grow a large acreage, says L. A. stockwell in "Iowa Homestead." One goes into the field early, husk out the well formed ears, that ripen first, and that are the right distance from the ground. Another selects the largest anå best ears he can find in his crib at planting time. Nine-tenths of all the corn planted is selected in one or the other of these ways. Those who select the ears while in the field are careful not to take an ear from a smutted stalk. Why so? Evidently because they think the resulting crop must be smutty. Now let us walk through the corn field with a man who selects his seed when the first husks begin to turn. Here the corn is all around us. Here is a nice large, early ear. It is picked and put into the sack. The next is passed; it is too high up; the next is too small; the next has smut on either the etalk, the ear or the tassel. It is passed. The next is picked; then two or three nubbins, then a stalk that is entirely barren is passed, and so on through the field until the sack is filled. The farmer husks it, hangs it up in a dry, airy place, away from rats, and feels that he has made a goor beginning toward his next year's crop.

But has he? Look at the growing stalk of corn for a moment. The organs of reproduction consists of a tassel and the silk. The pollen, light and feathery, made so for a purpse, is cari ied by insects or by the wind, from the tassel of one stalk to the silk of ano her. Every farmer who has planted two varieties of corn side by side knows that they will mix; they will mix even for a long distance. This being th $\mathrm{case}$, the big ear, selected from among the nubbins, or the smut-affected ears, or the barren stalks, is liable to be fertized by pollen from one of them, perhap frum all three. Now, if like produces like, and this farmer thoroughly believes that it dues when it come to horses, cattle, sheep, or hegs, is n t his future crop bound to be greatly lessened by using such seed? He knows that a thousand pound mare bred to an 1,800 pound Percheron, will raise a colt not so large as its sire, nor so small as its dam, but somewhere along about half-way between, repending considerably upon its lreeping. But he does not believe that his big ear, weighing sixteen ounces, will be reduced in size. He thinks that big ears can be gotten by small sires, though he knows big norses cannot. If you should a.k him if that was his belief he would no doubt deny it. But, if actions speak louder than words, the average farmer believes that large corn can be grown from badly sired seed. How, then, should we select our seed? Don't select it but grow it. In other words, plant a small plot of the best seed you can buy, and plant on a distant part of the farm, where jt will be as far as possible from other corn. Cultivate well and as scon as it is seen that some stalks have fallen behind and are going to be small, cut them out. Watch closely, and cut out every stalk that is not up to your ideal of what a stalk should be, before it tassels. From , this corn select the type that approaches the nearest to your ideal of perfect corn. Plant in the same way for your next seed crop. Try this plan and you will be surprised at the increase of your yield on the same land with the same cultivation.

Promptness in filling orders is very essential with a private trade in farm produce. It is one of the golden keys to success. If an order is sent, do not wait until some of the family are going to town, but send someone at onceE. E. Rockwood.

"And he stole the "possum from you," said the judge

"Yes, suh; en wuss dan dat, he not only cooked it, en eat it, but pick his teeth right in front er my do'!"

Jails were built for the especial accommodation of people who go about trying to live on what the world owes them. 


\section{The Largest Yield in Thirty-five Years.}

Mr. H. J. Lichty, of Blackhawk Co , Iowa, writes under date Nov. 23, 1900:

I have gathered my corn and think I am conservative in saying that I realized twenty per cent. better yield, and results, from planting "Pride of Nishna" than from common native sorts. I commenced planting May 10th and finished about the 25th, obtaining an excellent stand, verifying the truth of your statement that yo' 1 r corn was "seed corn, not elevator corn." In fact, my stand was too good if anything. I have never grown corn here as large: as deep grain and small cob, as from the seed I obtained
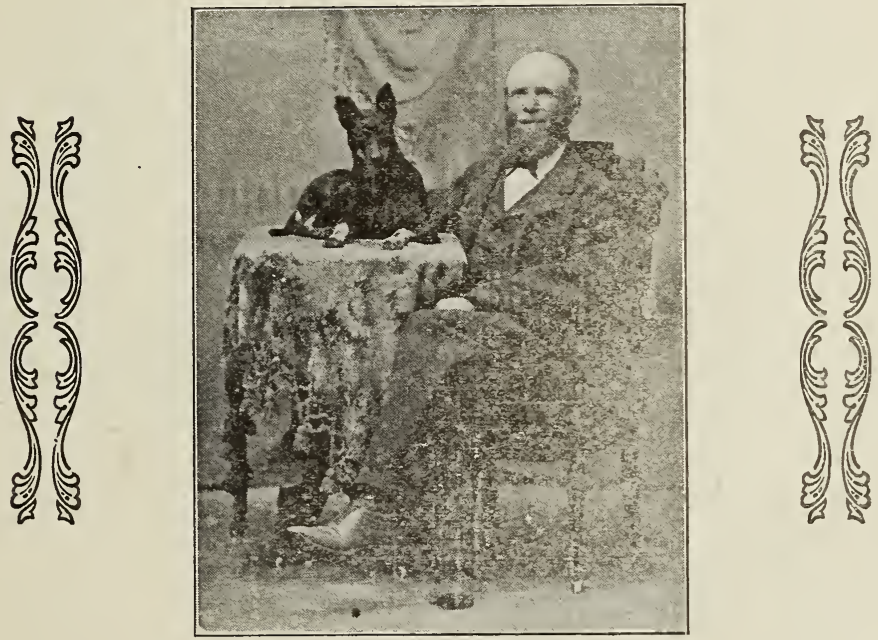

MR. H. J. LICHTY.

from you last spring, and this is to a large extent where we gained such good results in the increased yield. I have grown corn here for thirty-five years, and I never before obtained as many bushels of good sound, well-matured corn off the same amount of land. The experience of some twenty other farmers that I furnished this seed to, is similar to my own. It matures fully as early as any of our common native sorts.

While on a visit down in Brown county, Kan as, this fall, I met a gentleman, Uriah Siyler, and saw his corn grown from seed originally bought from you six or seven years ago. It was certainly a grand sight to see, as it was perfect in every respect. I have had quite a number speak to me for seed for another year, and trust they may obtain the same good results.

Blackhawk county is third county west of Dubuque, Iowa. J. J. R. R. R. \& Son.

P. S.-We have never seen nor met Mr. Lichty, but are advised that he is numbered among the largest, most progressive and substantial farmers of Blackbawk county, and was among our best customers of last season, having ordered, in all, something over 200 bushels of seed for his own use and that of his neighbors and friends.

J. R R. \& Son.

J. R. Ratekin \& Son: I received the seed corn ordered of you, promptly, and found same first-class; planted from 10th to 20th of May "Pride of Nishna" cultivated three times; "Silver Mine" planted on old land farmed 25 years, and I must say I have the best corn I ever grew, it is making fully 15 bushels more per acre than native sorts grown under like circumstances. A neighbor went through the field with me and said if he was estimating would say it was good for 100 bushels per acre. Its all right. 


\section{Iowa's Great Corn Crop.}

Director Sage, of the Iowa Weather and Crop Service has made the remarkable announcement that the corn crop of Iowa, this year, is estimated at the splendid average of 43 bushels per acre. Figured on this basis it is an increase of 25 per cent. over last year's crop which was considered up to the average for the past ten years. While this has been a good year, and other crops have also shown considerable increase in yield, none has shown such an increase as has the corn crop, therefore it is reasonable to conclude that there have been other agencies at work which have aided materially in the remarkable in. crease in the corn yield.

A mong them, and we believe chiefly, was the greatly improved varieties of seed planted, however, this was brought about largely through and by the agitation of better farming and better seed varieties by the Agricultural press of the state, including the "Iowa Homestead," "Wallace's Farner" and the "F'armer's Tribune." They each and all published a series of articles, beginning in the fall of 1899 and extending through three months or more, touching first on the manner of selecting seed, the "Homestead" filling some twenty pages of one issue, with articles and letters from among the best and most practical corn growers from all parts of the corn belt, especially Iowa, in which methods and manner of selecting seed corn was very ably and thoroughly discussed by over one hundred farmers and practical corn raisers, which was followed in an aftermath for many weeks. "Wallace's Farmer" also teemed with articles touching every point and every phase of the best methods of growing corn. Last, but not least, the "Farmers's Tribune" published a series of corn articles lasting for nearly three months when the corn growers were thinking of their next year's crop, consisting of able papers from the best farmers all over Jowa, Illinois, Nebraska and Wisconsin, but especially Iowa. In addition to this, that paper published a special edition of more than two hundred thousand copies, devoted specially and exclusively to corn, corn growing and to seed and seed varieties, and a copy of this edition was mailed to the address of every corn growing farmer in the state of Iowa, whose names had been furnished and afterwards verified by the postmaster at every postoffice in the state. This, with a similar agitation on the part of the other papers, had the effect of awakening a great interest among the corn growing farmers of this state. All they had to do was to follow the advice and directions laid down in plain print in these engines of progress. As a result of this wonderful awakening we received orders for and sold more seed, reaching to over fifteen thousand bushels, in Iowa, than all combined of any six other states, and we sold seed in thirty-eight different states during the season.

In connection with this we feel highly gratified to know that Iowa produced more corn in 1900 than any other state in this union, $\mathbf{3 5 6 , 0 0 0 , 0 ( 0 )}$ bushels that the average yield per acre was 43 bushels firom every acre of ground planted; more than seventeen bushels per acre above the average yield in the United States, in 1900.

What our improved varieties have done for the corn growers in Iowa, it will do for the farmers the same wherever corn can be successfully grown.

\section{J. R. Ratekin \& Son.}

Lee county, Iowa, Oct. 22, 1900.

In regard to seed corn obtained from you last spring would say results have been very satisfactory this season. Planted Mlay 3d to 11th: on good land; cultivated four and five times; I am now gathering 70 bushels per acre from it. I am selecting seed for another year, must say I think I have some model ears. Yes, I am well pleased. Yours truly,

T. H. BENTON.

Do not think the garden tinished when the seeds are sown. Cultivation for prevention of weeds and to promote growth is necessary. If you have planted free government seeds you may have to plant again and those who only cultivate to kill weeds will not secure a high measure of success. 


\section{It Beat Four Other Varieties From 17 to 37 Bushels Per Acre.}

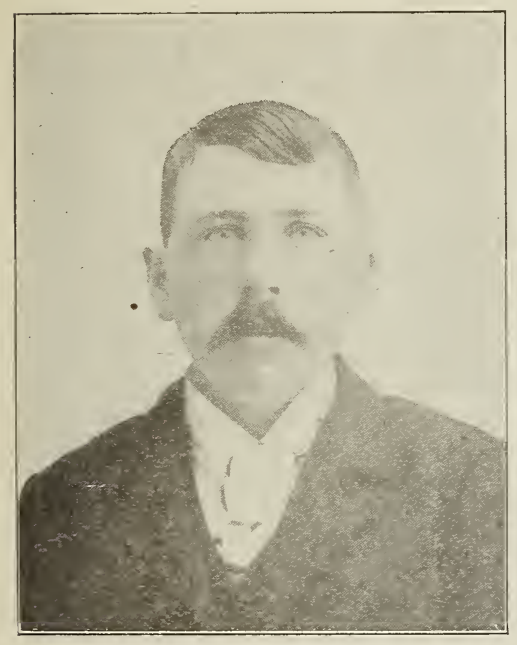

JAMES CARPENTER.

Lyon County, Iowa, Nov. 10, 1900. Mr. J. R. Ratekin \& Son.-Gentlemen.I have waited until after gathering my crop before writing you in regard to results obtained from the seed I got from you last spring and I am now ready to make an intelligent report. I got, as you know, just 100 pounds of seed of your "Pride of Nishna." This I planted on ten acres of ground with a drill May 4 th. The land was about half creek bottom and other half hill-side ground. It was plowed last fall, dis'ed and harrowed this spring before planting, (drilling) then four good plowings afterward. I harvested and measured, both the ground, and the corn obtained, ard found I got just seventy-seven bushels per acre from the land planted with your seed, and if I had not got my corn too thick I an confident that I would have got one hundred bushels per acre. From other varieties I grew under same conditions side by side with it, I only got from 40 to 60 bushels per acre. I must say that I am highly pleased with the investment and experience with the seed bought from you. I remain, Yours truly,

JAMES CARPENTER.

P. S.-Sioux courty adjoins South Dakota on the west and Lyon county on the ncrth, which is the northwestern corner county in Iowa.-J. R. R. \& Son.

Lucas County, Iowa, Nov. 14, 1900. J. R. Ratekin \& Son.-Gentlemen:I planted the seed corn I got of you "Pride of Nishna" on the 24 th day of May on good rich ground, checking it each way and plowing it three times with cultivator, and I have gathered an average of a little over $7 t$ bushels per acre from it. My native sorts made 60 bushels with the same cultivation, or about fourteen bushels less per acre. I am satisfied I would have got 90 bushels per acre from your corn except for a bad storm we had about the time the corn was in tassel and silk. Yes I am well pleased. Very truly yours,

\section{SAMUEL. N. BOYD.}

Johnson County, Iowa, Oct. 25, 1900. J. R. Ratekin \& Son:-I would have written you before now, but wanted to see how my corn turned out grown from seed obtained from you last spring. I commenced planting April 20 . which is exceptionally early for this latitude. The seed was perfect, giving 100 per cent. stand, cultivation fairly good. Matured and out of the way of all danger from frost by 1 th of August. We have just finished husking a field af 36 acres of the "Pride of Nishna" and have 1980 bushels of as tine corn as any one could wish. I have not gathered the "Silver Mine" yet but it too is all right. I like all of it first class and shall plant much more of it next year.

Yours truly,

R. A. Clanjian, Iowa City, Iowa.

Frank T. Clampitt, County Surveyor Hardin County, Iowa, November 17, 1900. J. R. Ratekin \& Son:-I am quite pleased with the "Iowa Silver Mine" seed corn I sent to you for last spring. Yield, from 60 to 65 bushels per acre. I shall plant it again next year. Very truly, 


\section{Twenty-seven Bushels More Per Acre.}

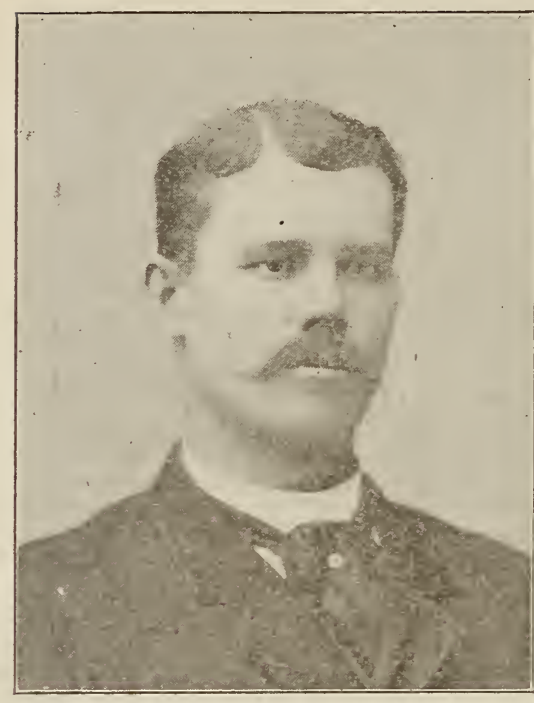

MR. M. F. OLDFIELD.

Du-Page County, Ill., Dec. 1, 1900. Messrs. J. R Ratekin \& Son.-Gentlemen:-I should bave written before with regard to results from seed corn, "Price of Nishna" and "Iowa Silver Mine," obtained from you last spring, but have raited until I was through gathering in order that I might write intelligently. I am now done. To commence, would say: I planted about I!ay 2.5th: obtained an excellent stand, cultivation ordinary gcod. Corn matured soundly before frost; ready for cr.bbing early in October; yield from actual measurement of ground and corn, "Pride of Nishna" seventy-two bushels per acre. "Silver Mine" was good but yield not quite up to "Pride of Nishna" Cbaracter and quality of each was indeed fine. Both were a success for me. We held a "Harrest Home" exhibition here this" fall. I exhibited samples of each variety and am pleased to say that I was awarded first prize on both varieties, and there was a large number of exhibits as well as sharp competition. My ground was not of the best, and other common sorts planted side by side with your corn made but 45 bushels per acre. all under like conditions, a difference of 27 bushels per acre, or over one-third in avor of crop fro n your seed. I am well pleased and have booked quite a number of orde s for səed for next spring. Its the best and beats anything erer befure grown here.

Tery tru'y yours,

M. H. OLDFIELD.

(Du-Page Co., Ill, is directly west of Chicago, and joins Cook Co )

McHenry County, Ill., Oct. 2t, 1900. Messrs. J. R. Ratekin \& Son.-Gentlemen:-Would say I bought one bushel of your "Pride of Nishna" yellow dent corn last spring, and planted it here on the 19th day of May on good ground, cultivated it tive times, level cultivation, rowed both ways. It matured in 100 dars, good well deve oped ears, many of them 12 inches long, grains large, many of them measuring $\frac{3}{4}$ inches long, on small cob. It is yielding 100 bushels per acre and is ahead of anything in this pirt of the country. My yield is just, double that grown on the opposite side of the road from native grown seed. Many have spoken to me for seed for the coming season.

E. C. BEEBE.

McHenry County lies next to Wisconsin line and next to Lake Michigan, except, Lake County which is the northeast county in Illinois.-J. R. K. \& Son.

Randolph County, Ills, Oct. 26, 1900. J. R. Ratekin \& Son:The "Pride of Nishna" yellow corn I obtained from you Jast spring was the finest corn, and gave best results of anything I have found for many years, and I have sent away for seed and tried quite a good many rarieties. Your seed was the last planted. MIay 25 th, and I find it the soundest, best and most perfectly developed ears of all, running from 8 to 11 inches long, well filled out at both ends; its just what I have been looking for for four or tive years.

Tery respectfully,

G. W. Love.

Rock Island County, Ills, Oct. 15. 1930.-My corn was badly blown down in August, but will say; "Pride of Nishna" is all right and one of the best varieties of yellow corn I have ever grown. It has good large ears, of uniform size and is early.

ROBT. Blazer. 


\section{"Corn is King."}

The United States produces more corn than all the balance of the world combined and its lead is lengthening and strengthening instead of shortening. The annual corn crop of this country represents more money than any other article of production in America. Wwo Billion IBushel Corn Crops have become common in recent years. However. from the increased and multiplied uses to which this cereal has been found valuable, our large accumulated surplus from 189-5-9-97.98 and 99, is gone, as recently demonstrated, when the bold and daring "Bull" Mr. Phillips, the biggest bull in American history, unpedigre $d$, put all the cubs and even old bears to flight that surrounds the board of trade, better known as the gamblers table where prices on farmers produce is practically fixed. Mr. Phillips simply bet there was not five million bushels of No. 2 corn in the country. that could be delivered in Chicago within 30 days. He won, notwithstanding the country was. scoured from east to west, and from north to south for erough of these enormous crops to fill this crntract and make good the sales of those who had contracted to deliver the goods within the timestipulated, namely, the month of November.

As before indicated "the world do move" in spite of grain gamblers and trusts, but it is said that "it 's an ill wind that blnw' no one any good," and in this case if no other it would seem that Mr. Phillips' wild escapade on the board of trade has demonstrated one tbing if no more, and that is that the great surplus of accumulated corn of past years is gone, and as we hope the days of Fifteen Cent Corn has gone, not s on, if ever to return.

It has not been so very long ago since corn was thought to be fit only for hogs and whiskey, but in recent years its uses as a food and for commercial purposes have been found to be almost untounded, and now the glucose retining companies alone manufacture more than thirty different artieles of commerce from corn, and the number of bushels consumed by these factories reaches into hundreds of millions.

In addition to this, during the past few years, the United States gorernment has taken steps to introduc 2 corn and corn products into mcst of the foreign countries, and for the calendar year ending Ost. 1st, last, 1930, the export markets have taken more than 2:9,000,000 bushels of our corn grown here in the corn belt of the United States, which is something over ten times more than ten years ago, and five times as much as was iaken only five years ago.

With this rapid progress in opening up new markets, and the multiplied uses found for American corn, and thus enlarging the market's demand, lays the premiees and foundation for the prediction that it will be but a short time until American cnrn will feed the hungry millions throughout the world, and settles the question of fifteen cent corn forever in this conntry.

Stimulated by these encouraging signs of the times, new energies have come to the corn growing farmer, and among other questions that naturally suggest themselves are, how can I secure the largest yield and most profitable results, from a given amount of ground?

\section{THIS IS EASY ENOUGH.}

After good ground comes good seed and good varieties, followed by good cultivation. No intelligent farmer will commence aright unless he is first possessed of the two former, with a will and determination to perform the third; for without gool soil, good seed, and good varieties, I trust no farmer will expect a premium crop. howerer, even with ordinary or poor soil he can beat and distance the average of the country by far if he is possessed only with the two latter things named. good seed and varieties, and p'enty of industry and proper cultivation. It is protit in anything that counts. If 30 bushels of corn to the acre pays expenses only, then 60 or 70 bushels would give a handsome profit.

Ratekin's "Pride of Nishna " yellow dent, or "Iowa Silver Mine" either will do this if you, $\mathrm{Mr}$. Farmer, will do your part. We want you to read every page of this book, and then say, "What others have done I, too, can do,"-J. R. R. \& Son. 


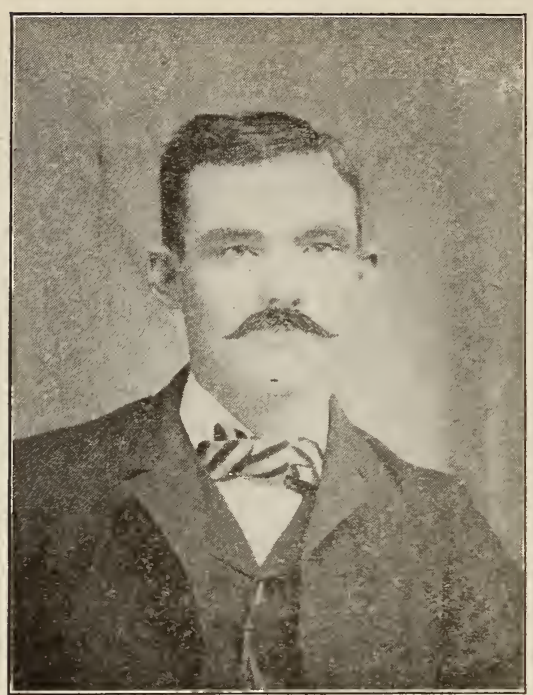

JERRY MCWILLIAMS.

Otoe Co., Nebraska, Nov. 15, 1900. Messrs. J. R. Ratekin \& son, Shenandoah, Iowa.-Geutlemen:-The seed corn I ordered from you last spring was received all right, on time and in first class order, aid i cnmmenced planting with lister May 7th and obtained an exceilent stand, however, the rains in June washed some of it out, but eren with this and only three plowings it y ielded seventy bushels per acre of as tine corn as I ever grew or saw. It was sinply immense. It was sufficiently matured to be safe'y out of the way of frost by Sept. 1st. Of course I am well pleased, and why shouldn't I be? "Pside of Nishna" is all right and so is the farmer who planis and gruws it. Very truly yours, JERRY MCWILLIAMS.

Nemaha, Co., Neb., Nov. 18, 1900. J. R. Batekin \& Son.-With regard to seed crn $\perp$ obtained from you last season, wou'd say it was planted in gosd time and I ottained a sp'endid stand. But heavy rains auring the early season washed much of it out. However, it made at the rate of five to ten bushels more per acre than other corn planted along by the side of it. Very truly yours, A. C. BRock.

Johnson Co., Neb., Dec. 14, 1900. J. R. Ratekin \& Son.-Gentlemen:We had a severe hail storm here June 16 h that almost ruined tne crops of this locality, therefore am unable to make an intelligent report of what results might have been from the seed corn I obtained from ycu last spring under fair or reasonable conditions. Sulfice to say, I never had as even a stand of corn before as from the seed I got from you. Judging as best I . can, I am free to say there were not one drzen hills missing $(n$ ten acres of ground planted with your seed. Yours very truly, H. Rron LUTERNAU.

Hon. C. H. Beethe, Representative elect, 5 th Neb. Dist., says, "Its all Right."

Elk Creek, Neb., Nov. 22, 1900. J. R. Ratekin \& Son.-Gentlemen:-The "Pride of Nishna" seed corn I obtained from you last spring was all right and a splendid variety of corn and did well for me.

Yours very truly,

C. H. Beетне, Proprietor Oak Grove Stock Farm.

Cedar Co., Neb., Nov. 11, 1900. J. R. Ratekin \& Son.-I am well pleased with results obtained from the seed corn I got from you last spring: planted May 17 th, got good stand and obtained a yield of 10 bushels per acre more from it than other sorts grown under same conditions by the side of it The only mistake I made was in not sending for more seed than I did. Shall want some of your white corn another year. I am Yours very truly, FERDINAND Houck.

Honest business is easily transacted. It is the dishonest business: which demands labor and brings trouble.

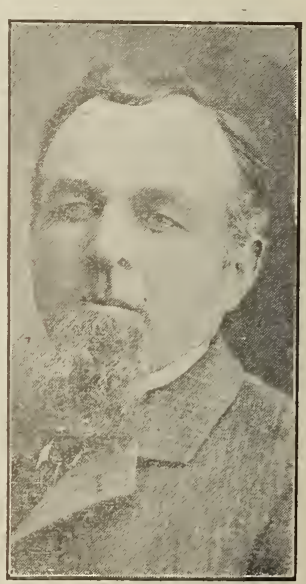

HON. C. H, BEETHE. 


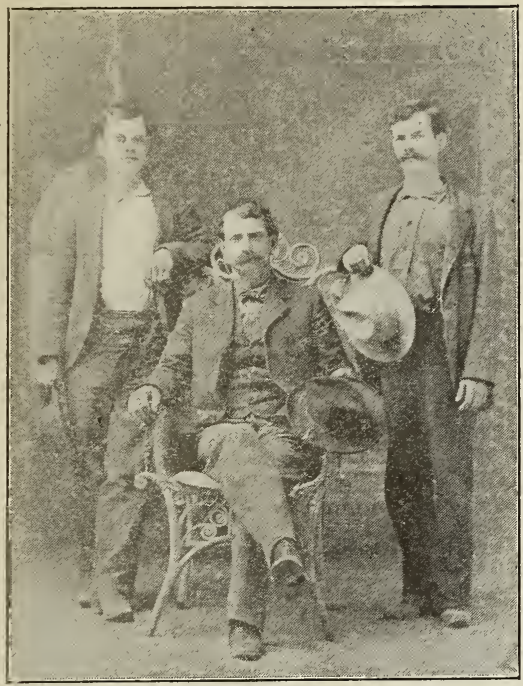

J. R. SHEARNON \& SONS.

Union County, South Dakota, Nov. 25, 1900. J. R. Ratekin \& Son.-Gentlemen:-I should have written you with regard to results from seed corn purchased from you last spring, before this but I cut my corn and put it in shock and I have now just shredded it and find that $I$ obtained 72 bushels of shelled corn per acre, your "Pride of Nishna." The seed grew good and I had an excellent stand running from two to three stalks to the hill and none missing. I cannot tell the date of planting, but can say it matured safely before frost and made good, sound solid corn of best grade. I am well pleased. Very truly yours,

\section{J. R. SHEARON.}

Jefferson County, Wisconsin, Nov. 14, 1900. J. R. Ratekin \& Son:-The seed corn purchased from you last spring was quite satisfactory. I obtainer a good stand and gave it fair cultivation same as other crop; matured soundly in about 110 days and yielded 115 baskets per acre. Ears were a foot long and well developed. Very truly yours, Julius Fischer.

Rock County, Wisconsin, Oct. 27, 1900. J. R. Ratekin \& Son:-The "Pride of Nishna" seed corn I ordered and received from you last spring has grown for me the best crop of corn I have ever raised. Planted May 25th, was ripe Sept. $15 \mathrm{tb},-28$ acres of it was the best corn grown in this part of the state, and will husk 200 baskets per acre. This corn will mature in Wisconsin safely in 90 days. Its all right.

A. D. Bullard.

Baraboo, Sauk County, Wisconsin, Oct. 27, 1900. J. R. Ratekin \& Son:The seed corn I got from you last spring proved all right. Planted May 19th, cultivated shallow four times, inaking a splendid crop.

\section{Respectfully, \\ WM. SAXE.}

Ionia County, Michigan, Dec. 16, 1900. J. R. Ratekin \& Son.-Gentlemen: -I obtained enough of your "Nameless Beauty" seed corn last spring to plant six rows, ten rods long, and as a result from it I husked twenty-five bushels of the largest, finest corn I ever raised in my life. It withstood the winds and stood up nicely where my other corn blew down, and ripened before frost. Everybody here who has seen it wants seed of it for next year. I am certainly well pleased with this corn. Very truly yours,

JOHN H. RITTENGER.

Rock County, Wisconsin, Nov. 1, 1900. J. R. Ratekin \& Son:-I planted the "Pride of Nishna" and "Iowa Silver Mine" seed corn I ordered and received from you last spring, from May 18th to 23d with a two horse check row planter, on black, sandy land, and obtained a perfect stand, not a hill or stalk missing, plowed four times with two horse cultivator; it matured finely, and I have husked the "Pride of Nishna" it yielding gord seventy-five bushels per acre. I think the "Silver Mine" even better, each making a full third more per acre than our native sorts. Its the best corn I have ever seen grow in the state of $-W i s c o n s i n$. Yours very truly,

O. J. LUNN.

It is a splendid way to round out a life by getting square with the Lord. The man who is on speaking terms with the Lord can speak to every neighbor, and no mistake. In order to have the very best neighborhood all the neighbors should be on this kind of speaking terms both with the Lord and with each other. A church in the neighborhood is a very good thing to have, but it is not of much account without some Christianity. 


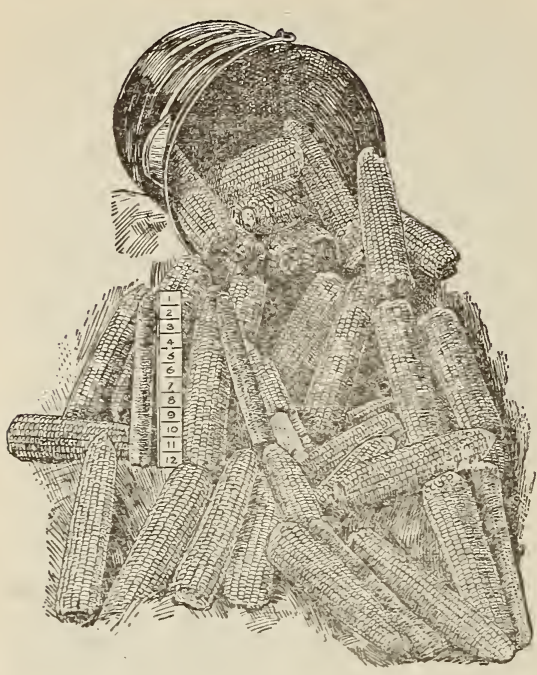

"PRIDE OF NISHNA.'

Planted in 38 states in 1900.

Ripley County, Mo,, Oct. 29, 1900. Mr. J. R. Ratekin \& Son.-Dear Sirs: -I write tosay that the "Pride of Nishna" seed corn I got from you last spring did well for me and I am well pleased with results obtained. Myself and boys were gathering some of it today and the boys said they never saw such fine large $\epsilon$ ars; they were as big as sticks of stove wood. I am equally pleased with the "Silver Mine," got at the same time. I commenced planting May 10th and on Sept. 10th I gathered, shelled and took to mill some of the "Silver Mine" and had it ground into meal. I had a good stand but owing to unusual wet weather I was unable to give it as good cultivation as I would have liked, but I had a splendid crop, as it was. Very respectfully,

J. C. Miller.

P. S.-Ripley County, lies in extreme southern tier of counties, the fourth west from Mississippi river, and Mr. Miller lives in Arkansas, however, his postoffice is in Ripley County, Missouri.-J. R R. \& Son.

Livingston County, Mo., Nov. 3, 1900. Messis. J. R. Ratekin \& Son:This has been a very dry season. no good rains from Nay to July last, and we have but half crop of corn. I plauted the "Pride of Nishna" and "Iowa Silver Nine" seed corn obtained from you last spring, May 1st, producing a perfect stand; had good cultivation on fairly good land, and while I did not get a full crop on account of drouth, I did get from five to ten bushels more per acre from the seed I obtained from sou than from my own common native sorts, all planted on same kind of land with same cultivation. I think "Silver Mine" stood the drouth even better than "Pride of Nishna."

Respectfully yours,

C. W. BOUCHER.

Jasper County, IIo., Nov, 23, 1900. Mr. J. R. Ratekin \& Son.-Dear Sirs: -The "Pride of Nishna" seed corn I bought of you has given splendid satisfaction. I planted A pril 1st and obtained a good stand, gave it fairly good cultivation, same as balance of my crop. It matured safely in 100 days from time planted and made much better yield than our common sorts, such as is grown here generally, with same cultivation on same ground by side of it. If you can take just a little of the ruff dent off then you will have corn that is perfection.

Very truly yours,

J. E. CARTER.

Osage County, Mo., Nov. 1, 1900. J. R. Ratekin \& Son:-I planted the corn I got from you A pril 6th, part on bottom and part on clay hillside, but owing to cold rains and unfavorable conditions did not get as gond stand as would have liked, but gave it good cultivatiı $n$ and obtained over 60 bushels per acre. July 8th I gatnered a well filled mess of roasting ears from it. I did not note date when it would be considered fully matured, however, it is so far ahead of native sorts, both in early maturity and yield there is no comparison. I find many ear's twelve inches long and well filled to the tip. Very respectfully,

J. F. MuLES.

Platt County, Mo., Nov. 23, 1900. Mr. J. R. Ratekin \& Son.-Gentlemen: -The seed corn ordered and receiver from you last spring, arrived on time and in good condition, and was planted May 7 th; it was matured, dried out and my boys commenced gathering Oct. 5th. The character, quality and yield were all gnod, very fine, and all my neighbors who have seen it are pleased and delighted with it. I have already had quite a number speak to me for seed for another year, and have sold over 30 bushels. I shall send to you later for seed of some of your other varieties. With many thanks to you for favors, I am, Very truly yours, MRS. J. O. KING. 


\section{Successful Corn Culture.}

Any one can grow corn after a fashion, but for best results aside from proper weather and climatic conditions, there are four other essential elements, all of about equal importance, that must be combined in order that success may be assured. They are a good farmer, good soil, good seed, and good culture.

\section{A GOOD FARMIER.}

It is said that "the result of warfare depends very largly upon the men behind the guns." This is equally true of every other human endeavor. The successful growing of a corn crop is no exception. "He that by the plow would thrive must either hold or drive," is as true as it is old. In this day of advanced agriculture success can only be attained by a good knowledge of the underlying scientific principles.

The chemical and mechanical conditions of the soil, the physiology of plants, as well as the philosophy of cultivation and plant growth, must be well understood by the farmer in order that he may be able to meet and overcome the ever varying conditions that confront him, identical conditions not returning once in a decade. Having the knowledge he will know when, how and for what purpose he manures or cultivates. To illustrate, suppose the soil seems quite fertile but is inclined to run together and pack hard on the least provocation and is very hard to keep proper tilth. It shows that the soil lacks humus, vegetable mould, or, as some call it. fiber. The remedy is to apply a heavy coat of coarse litter, such as coars ${ }^{a}$ manure, straw or stalks cut fine or a heavy crop of some green stuff plowed under. Any way to add decayed vegetable matter to the soil.

Or, suppose there is a too heavy growtl of stock, vines or branches, and a light crop of grain or fruit. This show s there is too much nitrogen in the soil compared with the other elements of fertility. The thing to do is to add phosphoric acid and potash to restore the proper balance, or continue to crop with some rank grower until the surplus nitrogen is taken up. Hence, we conclude the gocid farmer must be a close observer, a good reasoner, a deep thinker and a prompt executer. But however well informed may be "the man with a hoe" he cannot raise a good crop of corn without good soil.

By good soil we mean a soil that is thoroughly drained of surplus moisture, either naturally or artificially, and contains a l the elements of fertility, viz., nitrogen, phosphoric acid and potash, and a sufficient amount of humus in the right proportions, for the perfect development of both grain and stalk of the corn plant.

The virgin soil of the central west, including all of the upper Mississippi valley region, seems to possess the soil constituents in about the right proportion to grow the corn plant to perfection. The deep, rich mantle of black mould that covers this entire region seems to have been designed by nature for the home of this great cereal-the grain that, more than any other one thing, is making this country famous. A crop that is more valuable than any other single crop. But this great store house of nature (the virgin soil) becomes exhausted (or more properly speaking, unbalanced) in the corn producing elements after continuous cropping for a series of years, and begins to fail. For some reason the nitrogen of the soil is taken up more rapidly by the corn than are the other elements-phosphoric acid and potash. Hence the only thing to do to restore the equilibrium of the soil is to add more nitrogen. This can be done in three wass, viz., by resorting to commercial fertilizers, to the composite heap and barnyard manure, or to growing such crops on the ground as possess the power of extracting nitrogen from the air and returning it to the soil through their leaves, stems and roots. These are what are known as the leguminous plants, such as clovers, vetches and peas. The two former methods referred to are impractical on a large scale from the expense standpoint, hence we must rely on the latter viz., the clovers. The common, or medium, all things considered, is the best. Sow about eight quarts of clover and the same of timothy to the acre in early spring with Early Champion oats or spring wheat, as a nurse crop If the soil is light, such as is found in many portions of the central west, the clover is best sown real early so the seed may get well soaked by the late snows and early rains. 
When the proper time comes, sow the oats or wheat and plow all in together about three inches deep, and harrow thoroughly. By putting the grass seed down deep it pervents, in a great measure, the sun killing after the nurse crop is harvested. Cut the grain crop as early as will do and as high as possible. Your chances are good for a good stand of grass If you do not get a full stand, in the last of August or first of September harrow the stubble and apply more seed in about the proportion that the other sowing fell short of a stand. Do not be afraid to be liberal in the use of seed. It is the cheapest in the end. It is like feeding live stock liberally. If the soil is what is termed heavy it is better to sow the small grain and plow or spade it in and sow the grass seed on top and harrow thoroughly. It is best not to pasture the young clover the first year, especially not until the seed is ripe. If you have the live stock and do not want the hay, the best thing is to pasture the field off closely several times during the second summer. The accumulations of manure from the barns and feed-lots could be very protitably used on this ground after the oats or wheat was harvested, by spreading so thinly on the poorer parts that the grass would not be smothered. If the plan outlined has been a success, we have sufficient nitrogen in the soil to produce several crops of corn much above the average.

This brings us to the third element in the production of a corn crop-

\section{GOOD SEED.}

By good seed we mean that which has been handled so that all of its germinating power has been preserved, aided by a constitutional vigor implanted in the grain by a judicious selection, cultivation and environment that produces a pure or imploved variety. 'This may be done by the common farmer, but is generally best done by the professional seed corn grower. He generally knows better how to do this, and has the proper facilities for doing the work. This is (or soon will be) a business of itself.

The variety should be grown that matures readily in an ordinary season in your latitude. Remember, a small, ripe ear of corn is better than a large green one, and with proper management about as many bushels of small or medium corn can be grown on an acre as there can be of a large variety. Most of the large yields have been made with medium varieties.

Every corn grower should have access to three sizes of corn-large, medium, and small. If the weather conditions are favorable early, plant the largest variety that will mature in your locality. If for any reason you are delayed ten days or two weeks, as is sometimes the case, plant the early or medium variety. Or sometimes it is desirable to have real early feed; in this case plant the early first. Plant some improved sort. If you do not have the pure seed, procure it of some reliable seed.corn grower. On the subject of good seed the writer once heard the best corn grower in central Iowa remark: "As a bushel will plant eight acres, I would rather pay eight dollar a bushel for good seed than plant the common seed as a gift." Remember that the mere fact that corn will germinate is not sufficient. A stunted stalk of corn is like a stunted calf. It takes all summer to get to growing. There is also a difference in the constitutional vigor of different varieties of corn. Hence, if you have not a desirable variety of corn and do not thoroughly understand how to save your seed, you will do much better to get your seed corn from some reliable seed corn grower who does. Good seed is as important as grod culture.

\section{A GOOD STAND OF CORN.}

N. J. HARRIS.

Every farmer would like to have a good stand of corn. What is a good stand of corn? Most men will say that an average of three stalks to the hill is a good stand. A good stand of corn consists of an even distribution of the stalks over an acre of ground and not an average of so many stalks to the hill. Six stalks in one hill and nothing in the next will make an average of three and yet the results would be very unsatisfactory. I would rather have two vigorous stalks in every hill than to have an average of three all over the field with skips, making them from nothing to five. More mistakes are made by having too good a siand than is usually believed. Many farmers believe in "getting a plenty while they are getting," and for that very reason they plant thick and forget or neglect to thin. 


\section{Big Deal in Corn.}

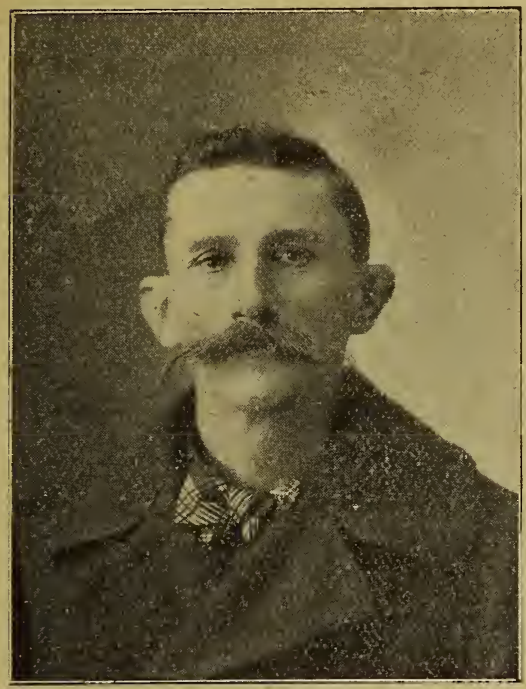

ABRAHAM MERRITT.

Undoubtedly one of the best pleased men in Page County Christmas day was Mr. Abraham Merritt. On that day he received pay for his supply of seed corn saved from this years crop, accepting from J. R. Ratekin \& Son a check for $\$ 1001$. Last spring Mr. Merrit bought three bushels of corn from Messrs. Ratekin for which he agreed to pay one dollar when his crop should be gathered in the fall. The yield was magnificent and th? quality of the corn very superior. Recognizing its ralue for seed, the senior member of the great seed corn firm made an offer for the entire yield, which was accepted, and Mr. Merritt is an even thousand dollars ahead by the transactionnot counting cost of planting, cultivating and harvesting the crop.-Shenandoah World, Dec. 28, 1900.

Shenandoah, Iowa, Jan. 1, 1901. Yes, the above is true. I would also say that I have grown "Pride of Nishna" Yellow Dent Corn for the past ten years and have found it to be a very superior variety over any thing I have ever before grown, and I have tried about all the leading sorts grown, so far as I know. While I had plenty of this seed saved myself, Messrs. Ratekin insisted that I should plant only seed grown and saved by them especially for thelr own use in growing stock for the season of 1901 .

In $1898 \mathrm{I}$ grew this variety side by side with two other good and well known sorts, all under identically same conditions, and obtained an average of 22 bushels more per acre from "Pride of Nishna" than from them. Again in 1899 and 1900 I did the same with about the same results, and I have no hesitation in saying that I have found and regard this corn amovg, if not the best and most profitable ever before introduced.

In connection with this it might be proper for me to say that I have known Messrs. Ratekin \& Son for the past thirty years, especially the senior member of the firm, and during all that time I have sold them more or less corn about every year, and in all our business transactions have found them to be gentlemen of integrity, and always ready to do right.

$$
\text { Respectfully, }
$$

ABRAHAM ḾLERITT.

\section{Large Yíelds of Corn, Etc.}

The largest yield of corn per acre ever known to be produced was that of J. B. Drake in South Carolina some years ago, in which he competed for and won a large prize. The yield on a measured acre was $255^{\frac{3}{4}}$ bushels. Another South Carolinian raised, on an acre, 250 bushels and a Georgia farm yielded 230 bushels on one acre.-Journal of Agriculture.

\section{"In Readiness."}

Lord Beaconsfield said, "The great secret of success in life is to be ready when the opportunity comes." This fact is made evident in the lives of men. Being ready for the propitious seed time means the fruitful harvest. When farmers realize that farming is a big business, and that each season has its time for sowing and for reaping, limited to days, peculiar to its own, he will make preparation, and good crops will reward his readiness. Order your seed corn for the coming season today. Be ready. 


\section{OUR VANITY PAGE.}

\section{STARTED UP FOR BUSINESS.}

The current issue of the Shenandoah Sentinel mentions the prosperous business of Col. J. R. Ratekin, formerly commandant of the Iowa Soldiers' Home in this city, and says: "J. R. Ratekin \& Son started the machinery of their seed corn establishment this morning. It will be remembered that they purchased the old plant of the creamery, to which they'have made extensive additions and now have a mammoth institution with some 30,000 or 40.000 bushels of fine seed corn to dispose of the coming spring. The whole institution is heated by steam, which also runs the machinery. There is a sheller and succession of blowers, fanning mills, elevators and separators. All the corn is hand sorted and tipped and butted and every bit of questionable corn is rejected, so that all the corn sold for seed is as nearly perfect as it is possible to secure it. The capacity of the shelling and packing machinery is 1,000 bushels per day:" -Marshalltown Times Republican, Jan. 3, 1901.

\section{TURNED ON THE STEAM.}

J. R. Ratekin \& Son had their large seed corn plant in full running order last Tuesday morning. This tirm kas about 75,000 bushels of corn, grown under their supervision this year - the largest amount ever before handled by them. Their plant is run by steam power and is heated also by steam. The corn is taken from the large cribs into the sorting room, where experienced men examine every ear carefully to see that it is perfect, and after taking off-both ends it is passed on to the shelling room, where it is shelled and passes through two blowers to take out all dirt and light grain, and then goes to the sacking machine. Everything about the plant is in first class shape, all being rebuilt the past fall and remodeled to suit the convenience of the business. There is one room for printed matter alone, of which this firm handles an immense amount. Mr. Ratekin is a veteran in the seed corn business and understands every feature of it thoroughly, and the large business they do is an indication that their experience is valued by the farmers all over the United States. We are glad. to see the signs of prosperity everywhere indicated about this plant. It is one of large institutions of the city and we wish them abundant success for the new year.-Shenandoah, World. January 1, 1900.

\section{0,000 BUSHELS.}

Messrs. J. R. Ratekin \& Son, who rank high among Shenandoah's seed corn growers and exporters, calculate on putting into their drying house this fall sixty thousand bushels of the finest and best seed corn ever anywhere grown in this heart of the "great" corn belt of the United States of America. When this seed corn is sold and shipped out the coming winter and spring, as it will be at least at $\$ 1$ per bushel, and that is a very low price to place upon it, it will bring in lots of money here to increase the circulating merium among us. Messrs. Ratekin \& Son have just built a large new addition to their already large seed corn establishment, thus making it easily the largest and most commodious seed corn house in the world. We understand they ship seed corn to all parts of the United States.- Shenandoah Post, Nov. 15, 1900.

The Prairie Farmer has called especial attention to the merits of the corn which was sent out last spring by Messrs. J. R. Ratekin \& Son of Shenandoah, Iowa. In their announcement, and also in our statement, great stress was laid on "Pride of Nishna." It was planted in thirty-eight states this season, and has again proven itself to be one of the earliest varieties of yellow dent corn in the world. Besides their "Pride of Nishna" corn, this firm deals very extensively in "Iowa Silver Mine" and sold a very large amount of it last year to Prairie Farmer readers. A little later on we want to give our readers a pretty complete description of the different varieties of seed which this firm have now matured and ready to put into their storehouses. 


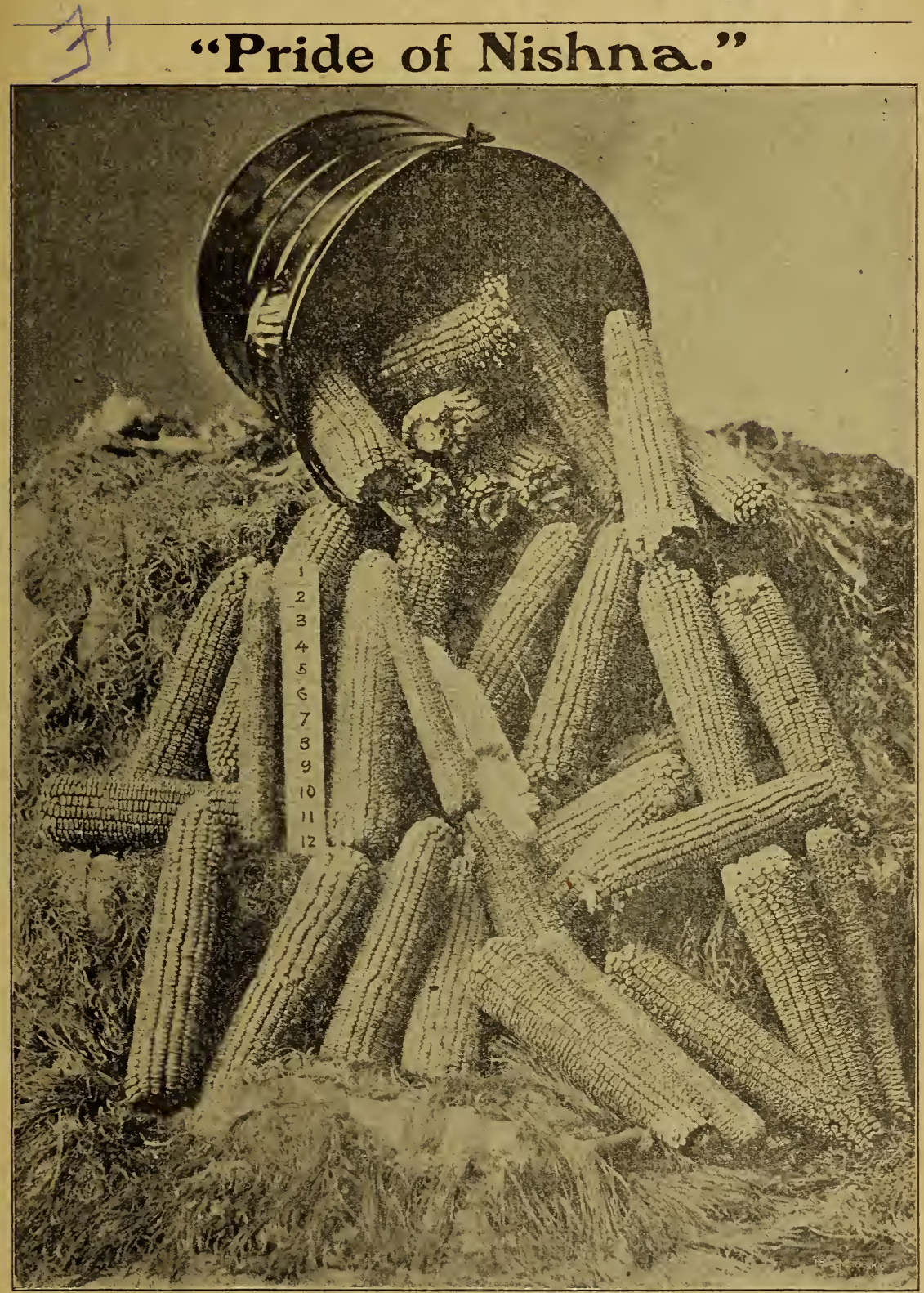

"PRIDE OF NISHNA" was planted and grown with profit in 38 States of this Union in 1900, including every county in the state of Iowa and Illinois, one hundred of the 114 counties of Missouri, and over 50 per cent. of all the counties in Kansas and Nebraska. SEE full description in following pages. 
It returns yields that Please, Profit and Astonish you: Be- sure an

For a number of years we have been watching this most excellent variety of corn which was originated here in the Nishna. Valley by one of the leading and best corn growers in this state.

This corn is the result of a cross and hybridization of two well known sorts, made about fifteen years ago, since which time by careful selection it has been bred up to the highest degree of excellence. Its type and characteristics have become thoroughly fixed, and it is as pure a variety as can be found and we think has as many or more real points of virtue than any yellow variety of corn we have ever seen.

The stalk is strong and vigorous with dark, heavy foliage with a deep,

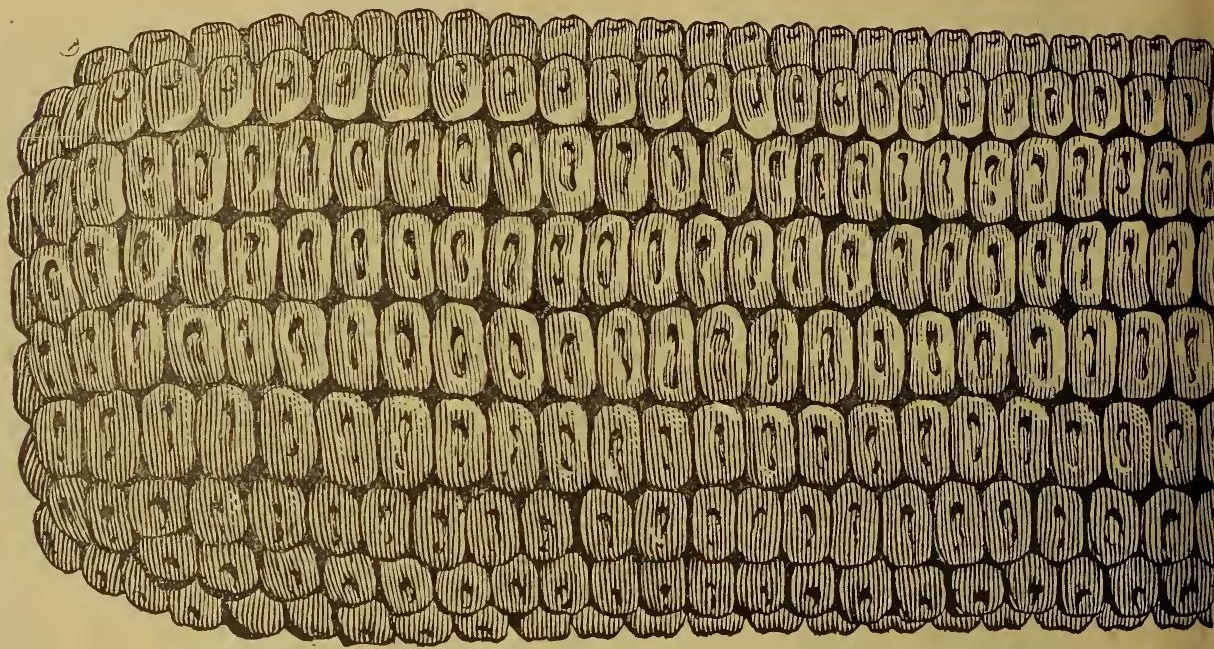

heavy root and is of great vitality, withstanding drouth to a wonderful degree. One of the most marked characteristics of this corn is that it never has any barren stalks. Every stalk has at least one large, well developed ear and many of them bear two good ears of golden yellow corn. The ears are remarkably uniform in size, color and shape, measuring about seven inches in circumference and ranging from nine to twelve inches in length, with from sixteen to twenty-four rows of very deep, solid grains to the row set solidly on a medium small sized cob. This corn is undoubtedly the earliest large eared corn that this country has ever produced. It will mature in from 90 to 100 days from time of planting.

The purpose of the originator was to produce a fixed type of large eared corn that would mature the largest yield of the soundest, best corn that could be matured safely in from 90 to 100 days, and in this he has succeeded admirably well. It is an enormous yielder on good, rich soil and at the same time gives a yield on poor, thin soil that no other corn does. The ears are well filled from butt to tip. It is easy to husk and easy to shell. The original cross and fertalization made was a congenial and suitable one, for growing a distinctively new type and variety of corn. It is like a vigorous young man of strong parentage, full of new blood and new life. It is full of vigor, full of oil and vitality and grows strong from the start. It has all the qualities to withstańd drouth and unfavorable conditions. It is as natural a yielder as 


\section{This is the Corn for you to Grow.} It's New, it's Grand and it's a Tremendous Yielder. \& $\&$ \& $\&$ \&

this stock. It is the Best all-around variety of yellow corn grown

weeds, and many of our patrons report that they grew last year 100 to 125 bushels to the acre. It will yield equal to or more than any other variety in the world under like conditions. If you want the golden yellow it's the corn to plant. We cannot too highly recommend this variety, it will not disappoint your best expectations. We know what it is, therefore pin our faith to it.

The cut on this page is a very correct representation of this excellent corn and was made for us from a photograph for our use, and is exactly the size of the ear photographed, being just seven inches in circumference and ten inches in length, which is an ordinary sized ear. 'This corn bas been so thoroughly tested and given such wonderful satisfaction and results, that we have no

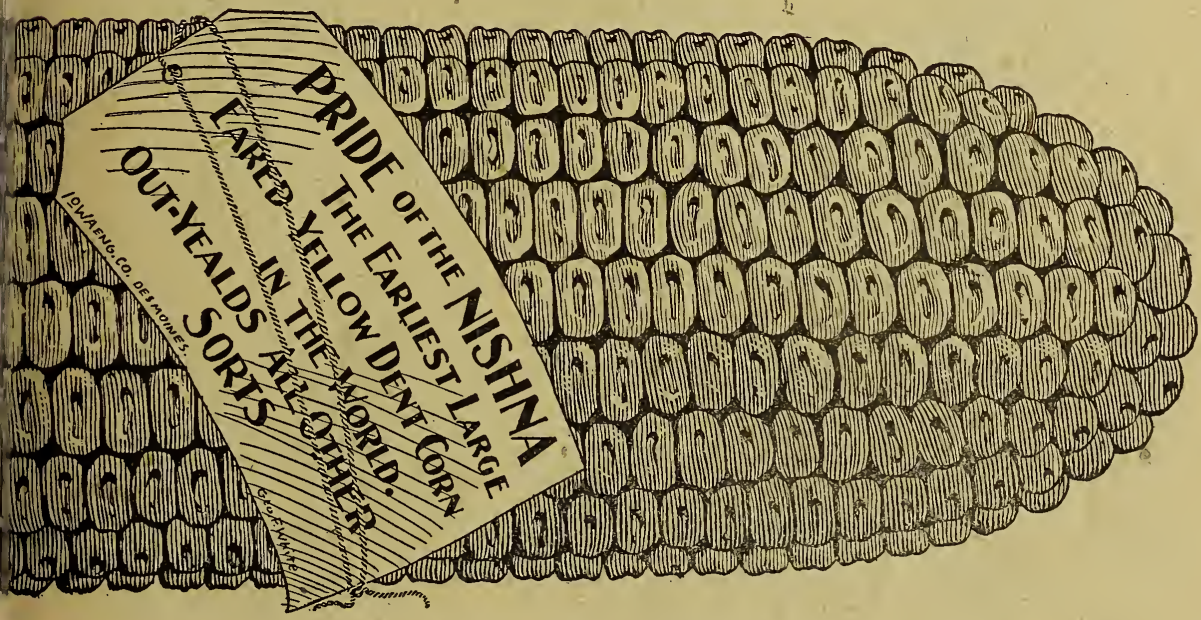

hesitation in recommending it freely to our customers, and we hope every farmer and corn grower who reads this will plant at least a part of his crop to this most excellent variety. Better yet; plant every acre with it.

PRICE:-By mail, postage prepaid by us, 1 lb. 20c.. 3 lbs.. 50c. By freight or express at purchaser's expense, peck $30 \mathrm{c}$., half bushel $55 \mathrm{c}$., one to 10 bushels, $\$ 1$ per bushel, 10 bushels and more 90e per bushel. Bags free, and aboard the cars here, in all cases.

Remember that our prices on seed corn are alike to all, of $\$ 1$ per bushel for "Pride of Nishna" yellow dent. "Iowa Silver Mine," white, and for "Ratekin's Gold Standard" yellow dent. For "Queen of Nishna," extra early yellow dent, \$1.2.5 per bushel. These prices include bags free aboard the. cars here, purchaser paying freight when seed is received at his station. In fixing our prices we have made them as low as good reliable seed can be sold for. Cheap, inferior seed can always be bought at cheap and reduced prices, but we make quality, not quantity, our standard of measure.

No doubt many novices, amateurs. and others without practical knowledge, experience. or capability will copy after our "book;" in fact. we have personal knowledge of those now waiting to obtain a copy of our book as soon as out of print before printing their own effusions, in order to get copy to go by. and thus palm off their catalogs as their own productions. Kind reader, should you see some of them. you can draw your own conclusions. 


\section{Lowa Silver Mine Corn.}

Iowa Silver Mine is unquestionably the most marvelous variety of corn ever grown or seen and one that will happily surprise every one who plants it. This corn was first intro suced in this state in the spring of 1894 , seven years ago, and in that short length of time it has almost revolutionized the corn growlng of the state of Iowa. Think of it, only seven years since this variety of corn was first introduced. Today there is not a variety grown in the United States that is so familiar to every farmer as Iowa Silver Mine, 215 bushels to the acre with ordinary culture. We don't blame some practical farmers for looking incredulous when this is mentioned. When we fisst heard of this we could not believe it. But the statement was verified from a source that we could not discredit, and since then has been reverified repeatedly. Just put on your thinker and think of it. The average corn crop of the United States was about 26 bushels per acre for the year 1900 and about the same for the two preceding years. There was over seven times this amount of Siiver Mine grown on une acre. Brother farmer, would you like to grow this kind of a crop? You may not, grow as much as this premium crop - developed, but by planting our "Iowa Silver Mine" on either light or heavy soil you can double your crop yield over common scrub sorts, and we assure you that you will make the best investment of your life for seeds, by getting enough of this superior and excellent seed corn to plant your entire crop for the coming season.

We bave more than twenty-five thousand bushels of this variety of corn for our trade for the coming season of 1901, selected from as fine strain as can be found in the world, and it went into our drying house in as good condition as corn was ever put up. There will be such a demand for it this year as never before and we want every farmer who reads this "book" to grow at least a part of his crop to Iowa Silver Mine, and we want you to order your seed today: nrder it before the rush comes, and before you neglect and forget it or lose our address.

\section{Description.}

Stalks grow to height of 7 to 10 feet, dependent on location and soil, and sets the ears about three to four feet from the ground, just the right height for husking. One peculiarity in this corn is that there is never any barren stalks, every one has an ear and many of them two good ears. The originator says that has been characteristic with it every year since he first produced this variety. The cut shown on preceding page represents a typical ear of this superb variety of corn and was photographed especially for this book. The type of this corn is very even and uniform; ears measuring from eight to twelve inches, and about seven inches in circumference, weighing one and óf ten as much as one and one half pounds is not uncommon. Like the ear photographed and shown on preceding page, they are of very uniform size and shape, with sixteen to twenty deep rows (usually eighteen) of pure, deep white kernels set on a small white cob. It is early matured, last year in ninety days from the time it was planted. The cob dries out rapidly so that it is ready for market or for cribbing earlier than any large white field corn in existence. In its yield it will surpass all other varieties of any kind or color. Seventy pounds in the ear will shell 62 pounds of corn to eight pounds of c jbs. It is adapted to a wider range of soil and climate than any other sort of corn offered. From Minnesota to Florida and from Massachusetts to California, it will yield a paying crop where other kinds are grown at a loss. It is in every way a distinct type of corn; order today while you have it in your mind, then you will have it when you need it. Remember that the freight is about the same on two bushels as it is on less quantities, as railroad companies usually charge for one hundred pounds for anything less than that much and after that in proportion.

Price: 1 lb. 20 z; 3 lbs. 50c, postpaid by us. Peck, 30c; one-half bushel, 55c; bu. $\$ 1$; ten bu. and more $90 \mathrm{c}$ per bu. The above includes new bags free on board cars here. 


\title{
Corn Growing.
}

\author{
How to Prepare the Land.-Choice of Seed.-Method of Cultivation.- \\ Harvesting the Crop.--Saving the Fodder, etc.
}

CORN IN MISSOURI.-J. R. RIPPEY.

The estimated acreage to corn in 1899 was $6,330,000$ acres and the yield $183,000,000$ bushels, an average of less than 30 bushels per acre for the entire state. While this average, considering the cold, wet, unfavorable seed time and the drouthy conditions that prevailed during August and September and the great variety of soils and conditions to contend with over so large an area, is fairly good, can ic not be largely increased by better methods of cultivation and more care in conserving soil fertility and moisture. At an average price of 25 cents per bushel, rent of land worth $\$ 2$ to $\$ 4$ per acre, labor $\$ 1$ per day without board and the additional expense of keep of team and the wear ard interest on machinery and harness, it is doubtful if 3 ) bushels per acre will prove remunerative. If not, then the farmer that produces less than that amount has lost money, or at least has not received a reasonable compensation for his labor and expense.

The seeding of corn is an investment, the returns from which are largely in the hands of the farmer. True, there are irsect pests and climatic conditions that he cannot control but he may conduct his farmlng operations so as to reduce these evils to the minimum. In the first place the seed should be selected with the greatest care; better this be done in the fall, taking only well matured ears of the desired type, have them thoroughly cured out before placing in bulk and then placed where rats and mice cannot destroy. The farmer should remember "No seed, no crop;" that a well-cared-for grain will develop a more vigorous plant than one that bas been sapped of much of its vitality; that this vigor is necessary to rush the plant above the young wee's and hasten the period of cultivation. The preparation of the seed bed must not be neglected. Whether the ground be broken with a turning plow, then pulverized with the disc or harrow, or if the lister ard drill be used, there is only one successful way to do it and that is to be thorough in every operation. The plowing should be deep, all the ground should be cut and all vegetation or old matter. should be turned under with it. The soil must be pulverized not only on top, but deep down and throrgh. Don't attempt to deceive yourself or the corn plant by a little loose dirt and a smooth surface on top whise the ground is hard and c'oddy below.

When the plant is up, cultivate at the earliest moment practical. Don't wait for the weeds to grow. Stir the ground that it may keep them from growing, and that moisture, absolutely essential to the growth of the corn plant, may be conserved by the loose soil mulch you have prepared on the surface. Keep on cultivating when opportunity offers. Never let a hard crust of soil form nor a coat of weeds grow if pissible to avoid it. Remember that the corn plant is a surface feeder, that its roots seek nourishment near the top of ground and should not be disturbed. Deep cultivation may not reach these at first. Later on it must be avoided, but the field must be kept free from weeds and the soil mulch maintained as long as jou can get through the field without injury to the plant.

The farmer will find it un profitable to attempt to produce corn on land where the fertility has been exhausted. A miner would not think of paying ten dollars for working a ton of ore that would yield but four. The cu tivation of an acre of poor soil that will yield but 20 bushels will cost as much, generally more, than a fertile acre that will yield sixty. If followed, the one will bankrupt the farmer, th 3 other will make him prosperous. It is probable there are but few acres of ground in Missouri that under favorable conditions and thorough cultivation would not produce sixty bushels of corn to the acre or double last season's average, after a good crop of clover or cow peas had been turned under. Leguminous plants grown upon exhausted or 
thin soils not only make a profitable crop but store up fertility for those that follow. Soil fertility must not be neglected. Corn on thin soil will never prove profitable. Make the soil what our farmers can make it with the aid of clover and cow peas, and without cost, and the annual production in Missouri will be three hundred million bushels and the yield at least fifty bushels per acre.

\section{Principles of Corn Culture.}

Select good seed; replanting seldom pays. Plant when the oak buds begin to leaf out. White varieties are best for domestic use. The yellow sorts as a rule are richer and contain most nutriment for stock, and adapt more readily to the soil. Large-growing varieties as a rule are late to mature and should be planted on the richest and most moist ground on the farm. Early-maturing varieties should be planted on the prorest, dryest, most sandy land on the farm, as such ground is most sensitive to drouth.

Most Mis ouri soils grow both stalks and ears too hioh. Select seed from low, stalky stalks. To grow new varieties, a cross between two given sorts, p ant in alternate rows; as soon as the tassels of silk appear, cut off about 75 per cent of the tassels of the most undesirable stalks leaving the balance for

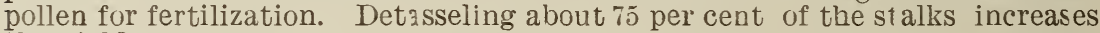
the yield.

Plow sandy soil in the fall, harrow and thoroughly pulverize before planting. Clay soil as a rule is best plowed in the spring Fall-plowed ground. if run together by rains during winter and early spring, should be replowed or soil loos ned with a to-horse cultivator. Most ground will produce best if plowed deep with a little sub-soiler under the plow, or followed by subsoil plow breaking up the bottom of the furrrow. If the ground is too cloddy for the harrow to pulrerize, use a clod-crusher, which is a wooden imple'rent made of three $2 \times 12$ inch planks, edges lapped and spiked together 8 feet long. Plant with two horse planter, three grains in a hill, $1 \frac{1}{2}$ to 2 inches deep.

Early cultivation subdues weeds and keeps ground mellow. Plowing and cultivating wet ground as a rule, will injure the soil, but the farmer who has much to plant and cultivate, often cannot wait until all gets in right condition, but he can plo $\pi$ his dryest land tirst. Such elements as unfavorable weather we cannot control. A great mistake is that some farmers make no allowance for unfavorable weather, and farm too much land. All will admit that two acres well treatod will yield more than three half treated or neglected. Weeds have to be subdued to keep them from robbing the corn of moisture. A proper regard paid to the destruction of weets and thorough cultivation will also increase the fertility of the soil by exposing the surface

- of the soil to the action of the elemeats to be made productive thereby. Frequent cultiration will preserve a mellow condition of the surface, so that the moisture rising from below may be held until it can be appropriated by the roots of the plant. JAC(B FAITI, in Journal of Agriculture.

To do good work in corn raising there are other requisites besides "knowing how." The most experienced farmer would make but a poor list of corn glowing without the assistance of the seedsmen to furnish gocd seed; and altho :gh most farmers save their corn seed from year to year, this, in many cases is carried to excess, and frequent planting of the same seed on the same ground will account for many failures to raise heavy crops. But to the s edsmen, after all, is due the improvement of corn varietics; and the experimentation necessary to the development of new and better sorts is due entirely to the laburs of the seedsmen, who are ever on the alert ts produce or introduce what they bolieve to be improvements upon older varieties. Then comes an equally important factor in the production of a profitable corn crop, viz., the makers of the various improved implements which play so important a part in the tillage, cultiration and final stages of the growth and the harvesting of the produce. With the latest improvements in plows, seeders, weeders, listers, etc., etc., in corn growing. For this great boon we are indebted to the progressive firms of implement makers. Many of their productions should be carefully studied by the wide-awake farmer.-J.R.R.\&S. 


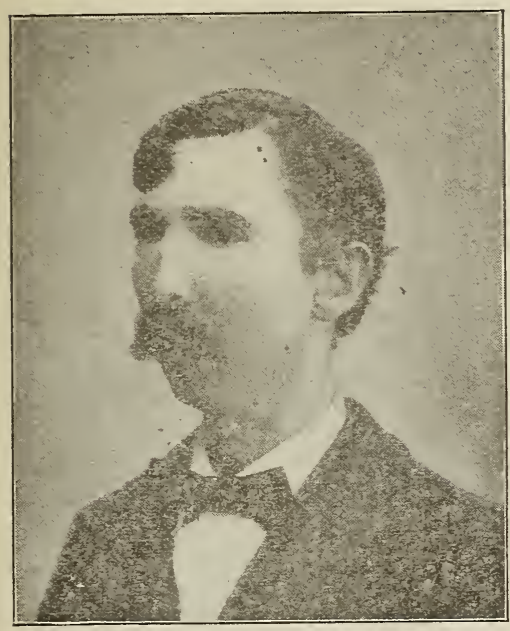

G. O. WALTHALL.

Chickasha, I. T., Jan. 27, 1900. Mr. J. R. Ratekin, Shenandoah. Iowa. -Dear Sir:-I ordered and receired from you some of your Yellow Deat seed corn five rears ago. Ever since then I have grown it. It always ripens and matures here before dry weatber sets in and before hot winds come, and I have go-d corn whether others do or not. My seed of it is becoming acclimated and does not ripen as early as when I first got it. I want new stock and supply. If still in the business send me your Catalog and prices. Respectfully,

G. O. WALTHALL.

Chickasha, I. T., Feb. 11, 1900. J. R. Ratekin \& Son, Shenanddah, Jowa. -Dear Sirs:-I mailed you my order for ten bushels of seed corn on the 10th. I want fire bushels more of the same kind, "Pride of Nishna" Yellow Dent. Ship the two orders together if you haven't started the first. I send my personal check, as I live twelve miles from town and can't get draft to send today. I have a farm of 1,000 acres in cultiration and grow corn for feeding purposes. I expect to require my tenants to plant this corn from now on. Its the sure thing, and the best cattle corn in the world. I could enumerate many of its merits over other sorts I have grown, but expect you are over-run with such letters.

\section{It Stands the Test.}

Chickasha, I. T., Oct. 1, 1900. Mr. J. R. Ratekin \& Son.-Gentlemen:When I received the 15 kushels of "Pride of Nishna" seed corn from you last spring, I planted 10 bushels of it on my own farm and fields, and the other five busbels I dirided up and distributed among my neighbors and friends. The 10 bushels I planted myself was planted the last week in March, along side by side with what we term our native sorts and got a fairly good stand, however, it turned cold and was very wet following the planting, remaining wet until June 16th. On the 18th day of June I gathered a very fine lot of roasting $f$ ars from it, at which time native sorts had just begun to tassel and silk. This corn besides being a sure oropper for th s coun ry, is murh earlier, being small cob with deep grain, making it the most desirable corn for fattening stock I have ever grown or handled, and I believe it will make more corn per acre with less rain, and oz thinner soil, or poor land, than any corn ever grown in this country. After many years experimenting with corn best adapted to this climate and soil, and for feer.ing purposes, I have decided to grow nothing but your "Priche of Nishna" yellow dent corn. Its the corn for the Southwest and can be grown with profit here regardless of early drouth, hot winds and other difficulties we have to contend against.

Very respectfully,- Georae O. Withall.

Gonzales County, Texas, Oct. 30, 1900. J. R. Ratekin \& Son.-Gentlemen: -The year 1900 is une long to be remembered in 'Texas for the rains, floods and insects. The "Silver Mine" corn I got from you was planted A pril 21st and under all the unfarorable conditions named it still made good corn. I shall plant it again next year. It is all right.

Respectfully yours,

Aug. Juengerman.

Worthem, Freestone County, Texac, Oct. 11, 1900.-I planted the "Iowa Silver Mine", corn obtained from you March 21st after which we had heavy rains for about ten days. Our native corn failed to come up and I had to plant over again. The "Silver Mine" came up all right and made good crop of corn. Yours, etc., G. K. WiLliaMs. 


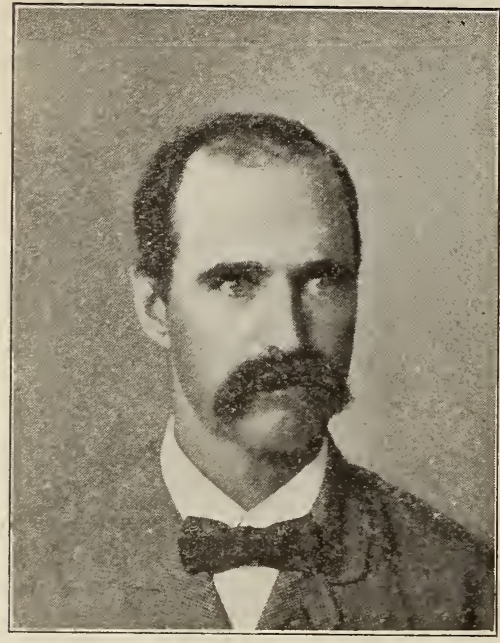

PAUL REAUME.

Ellsworth County, Kan., Jan. 31, 1900. Mr. J. R. Ratekin \& Son.-Gentlemen:-Inclosed find r rder made out for 35 bushels of your seed corn, and also draft to pay for the same. Ship via Union Pacitis. If your seed is as good as represented by sample and what you sav, you will get a number of other orders from here. Very respectfully. PAUL REAUME, Prop. Elk Horn Stock Farm.

Ellsworth County, Kans., Feb. 25, 1900. Mr. J. R. Rarekin \& Son:-I have received the seed corn I ordered from you and must say that I am well pleased. Such seed certainly ought to grow a good crop. I have given your address to quite a number of our leading and best farmers and think you will receive quite a good many orders from here. Very respectfully,

PAUL Reaune.

Ellsworth County, Kans., Nov. 1, 1900. Mr. J. R. Ratekin \& Son.-Gentlemen:-I write to say that this has been quite an unfavorable year with us here for corn, being struck with an early drouth at about the time corn was making itself. and most of onr corn was badly injured from this cause, however, the $3 \tilde{5}$ bushels of seed I got from you proved a very profitable investment to me, as it was fully two or three weeks ahead of our common native sorts, and consequently made much better corn. With best wishes for your success, I am,

$$
\text { Yours very truly, PAUL Reaune. }
$$

We are advised that Mr. Reaume is numbered among the leading farmers and ranchmen of Ellsworth county, and as a result of his interest in calling attention of friends to our seed, we sold something over 200 bushels lastspring in his neighborhood.--J. R R. \& Son.

Ellsworth County, Kans, March 28, 1900. J. R. Ratekin \& Son, Shenandoah, Iowa.- Your very complete letter of Feb. $23 \mathrm{~d}$, was duly received. At time received we were jus' entering the worst storm of the season, and the snow has now gone and we are now listing our land for corn. I know all about Mr. Paul Reaume. He is a large farmer, and a cattle man. I am going to trust to your honor and depend on rou to send me such varieties as are best suited to our climate and soil. Ẏou say jou sent Mr. Reaume 35 bushels of your seed,allright you may send me 35 bushels of your field corn, and a peck of your "Evergreen Sweet Corn," and on reseipt of bill will send you check in full parment. Remember I am depending on your honor to send me such varieties and sorts as are best suited for this climate and soil.

$$
\text { Yours very truly, } \quad \text { F. G. BABCOCK, }
$$
Pres. The Eden Park House and Cattle Co.

Ellsworth County, Kans., Nov. 12, 1900. J. R. Ratekin \& Son.-Gentlemen:-With regard to the "Pride of Nishna" seed corn I ottained from you last spring, would say this has been a bad season on account of drouth, however, I am obtaining about, 30 bushels per acre from crop grown from your seed, which is double cr fifteen bushels per acre more than that grown from our native sorts here. I planted, listed, May 1st and it matured Aug. 1st.

Yours very truly, JOSEPII W. HugGINS.

Greenwood County, Kans, Oct. 20, 1900. J. R. Ratekin \& Son:-The seed corn ordered from you was all right and first class, but dry weather struck us when corn was tasseling and silking and as it is we are getting but 30 to 40 bushels per acre, however, crops grown from your seed are yielding from 10 to 20 bushels per acre better than from native sorts. 


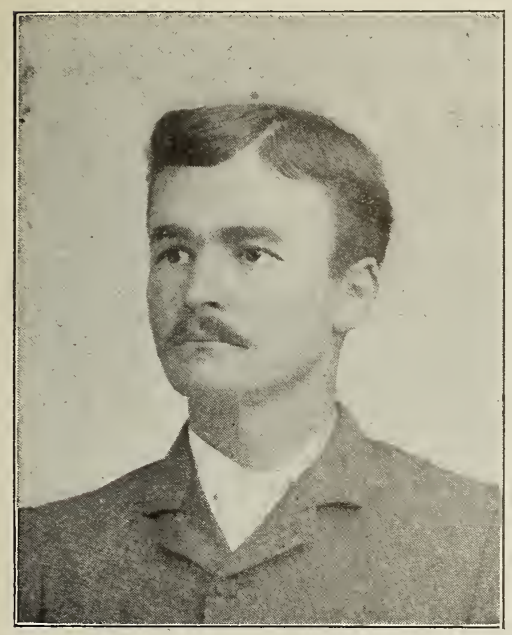

C. B. PERRY.

Morehead $\mathrm{Co}_{s}$, Louisiana, Sept. 20, 1900 J. R. Ratekin \& Son, Gentlemen:Yours of recent date received. I am pleased to say that out of four varieties of coln that I planted this year, "Iowa Sliver Mine" that I ordered from you takes the cake, making 60 bushels per acre, planted May 10th and worked twice with cultivator. One other sort planted March 28th, worked five times made 3.5 bushels per acre. Two other sorts making 15 bushels per acre with same work. Hoping you people will find ready sale for your seed all over the south, and the many farmers be benefitted by plantirg it, I remain

Yours very truly, C. B. PERRY.

Saginaw, Tarrant Co., 'Texs, Dec. 3, 1 00 . J. R. Ratekin \& Son, Shenandoah, Iowa, Dear Sirs:-I planted seed corn shipped direct from you last spring and will say. that I did the right thing, for this has been a trying season in this part of Texas, and some made a failure while others did better or medium. The "Pride of Nishna" and also "Iowa Silver Mine" that I obtained from you did well for me and ga ve excellent results I planted about March 10th, saw first silks May־28th. I find plenty of fine ears of Silver Mine with 24 rows, and notwithstanding the unfavorable season and conditions, 95 ears of "Pride of Nishna" weigh out one bushel of 70 lbs., so I am well pleased with both varieties, "Silver Nine" and "Pride of Nishna." They are the sure thing for Texas. Yours very truly,

\section{J. W. DAVIS.}

Reily Springs, Hopkins Co., Texas, Oct. 1st, 1900. In regard to the seed corn bought of you last spring would say it is turning out well and giving good results. I have just tinished harvesting my crop and have fully decided to plant no other varieties of corn. I find that your corn matures and is fully three weeks earlier than our native sorts, which is a $g$ eat advantage in event of short season from early drouth. I planted Iowa Silver Mine, altho I think for stock and feeding purpo:es "Pride of Nishna" is best, and for roasting ears everybody should plant Stowell's Evergreen Sweet Corn, some of which I obtained from you lastspring. This year was my first experience with northern grown seed corn, and I failed to get it thick enough. I find from experiments made with your seed, that it makes better corn to plant it twice as thick as we do our native sorts, or three grains in a hill 3 feet and 8 inches apart each way, and if in drills, one grain every foot in the row. Good varieties of northern seed corn is the sure thing for this country, and it will pay to send and get fresh seed every three or four years. Respectfully,

Thomas F. VICKERs.

Madison Co., Texas, Nov. 12, 1900. J. R. Ratekin \& Eon:-This has been an unusual year in this part of Texas for corn. The early part of the season was very wet and much of the corn was drowned out and choked to death from w. eds and grass. I planted the "Silver Mine" seed I got from you April 1st, very late for this locality. Some of my neighbors laushed at me for planting northern grown seed on my good new ground, but as smon as it was up and begun to grow, they changed their jdeas and expre sed much surprise to see how it grew, and in 55 days from time it was planted it was in silk. I had an excellent stand, but made one bad mistake by thinning it to one stalk to a hill. However I left some as an experiment three stalks to a hill, every one of which had as good or better ears than where only one was left. Your corn is all right. 


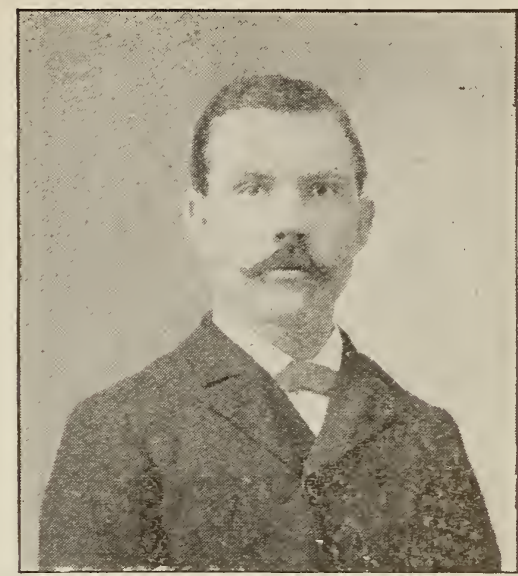

IV ARTHUR A Yers. Proprietor Hully Gruve Herd pure bred Poland China swine, Trenton, Gibson Co. Tenn.

Trenton, Gibson Co, Tenn., Nov. 5, 1900. Messis. J. R. Ratekin \& son: -With regard t) the ten bushels of seed corn I obtained from you last spring: I bag leave to say it was more than satisfactory. I obtained an exc llent stand, planting from the 1st to the 15th of May. That planted first was matured and ready for the shock Aug. 15. All planted from your seed was from 15 to 21 days earlier than corn grown from our native sorts. In addition the yield was fully one third more better corn, and snme say it will go double what the common native sorts will. I am delighted with all of it. and it is hard to tell which of it I like best. When walking through the "Iowa Silver Mine" I thought it best: when I went through "Pride of Nishna" it looked the finest, and after" viewin! "Ratekin's Nameless Beauty" I was even more delighted with it, so yc u see in deciding this question and point $I$ am like the famous "Tom" Watson "don't know where I am at." But it is all, all right and I am confident the change from jour locality to this is a most desirable one. Tery truly yours, W. ARTHUR A YERS.

Rives, Obian Co., Tenn., Sept. 3. 1900. MIessrs J. R. Ratekin \& Son:Please send me a sample of your "Turk ish Red" winter wheat, with descriptive circular. The seed corn I obtained from you last spring did well. The last I got was planted July 1st and we had roasting ear's from it today, 63 days from day it was planted. I think this dce ₹quite well, having grown a crop of wheat first and then a crop of corn afterward nn the same ground. My yellow er rn made very large ears with but one plowing. Kindly give me lowest price on wheat and oblige, Yours rery truly,

C. A. HENDON.

Simpson Co., Kentucky, Oct. 26, 1900. I take pleasure in saying that the seed corn obtained from you last spring was first class ard I got a tine stand. Howerer, uwing to continued wet weather during the season for cultiration, it had but little work and I obtained but 10 bushels per acre. It matured fully two weeks in advance of our native sorts. I divided the seed I got of you with two of my neighbors and they are each very much pleased with it. Respectfully,

J. II. RutherFord.

IcCracken Co., Ken, Oct 21, 1900. J. R. Ratekin \& Son:-The seed c rn I ordered and got from you last spring was all O. K. arid of strong germinating power, all glowing and making fine stand. I should say it matures fully th ee to four weeks before and ahead of our native or common sorts grown here. Many of the stalks have two ears on them. Very respectfully, H. J. Boldry.

The man is rich who has learned to attend to his own business: who has a large number of intelligent friends. who is loved and respected by his family atd who may be found in church on sundays and attending to his business on week days. 'The man is ve'y wealthy who is rointed to ly passersby as a prominent and progressire man, and who is liked by all who know him. He is wealthier than the millionaire, who is often deservedly despised.

Any staple product of the farm, if of superior excellence, will command the highest price. 


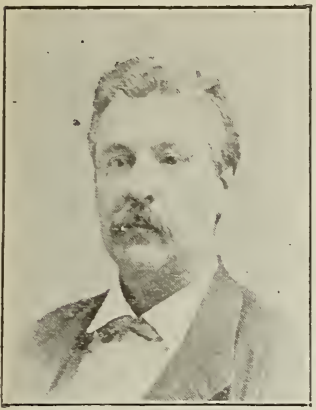

J. G. B. Erwix. Tice President for the Georsia Nat'1 Berkshires Record Assu'. Breeder of high class Berkshires and Fancy Fowls.

Erwin, Gordon Co., Ga., Nov. 1. 1900. Messrs. J. $\mathrm{R}$ Ratekin \& Son. Shenandoah, Iowa.-Gentlemen:With regard to the "Iowa Silver Mine" seed corn I $\mathrm{g}$ it from you last spring, would say: I planted it on a piece of ground 160 steps long and 80 wide; the ground planted on was very poor upland, but was manured last, fall. The seed grew to perfection and I obtained a first class stand, but the fore part of the season was vely wet, and then turned off very dry and it had but two plowings, however, I gathered $65^{\frac{1}{2}}$ bushels from it, and if it had not been for the extreme dry weather it would have easily made 100 bushels, but under the conditions I think it a very fine showing, especially so when I tell you that on the same kind of land under similar conditions in every respect, I only got a little over one-third as much corn from our common native sorts, off the same amount of ground

When I first got this seed and planted it some of my friends and neighbors laughed and poked fun at me and said it would never make anything except a little furage, but later when it begun to show itself, it was the wonder and admiration of every one who saw it, and it was a beautiful sight 10 see. A great many have spoken to me for seed and I am contident I will have orders for much more than I can supply. Kindly advise me what you are going to charge me for what I shall want. Please ship me two or thee bu-hels in the ear at your earliest convenience. Write me at time you ship and oblige, Yours very truly, J. G. B. ERWIN, Mgr. Erwin Stock and Poultry Farm.

Doredale, Baldwin County, Ga., April 19, 1900. Messrs. J. R. Ratekin \& Son.-Gen lemen:-Please find enclosed two dollars for two bushels more of your "Iowa Silver Mine" seed corn, white. I want tbis seed to plant on bottom land after oats are cut and taken off. The other two bushels of seed I got from you is up and it is looking as nice as nice can be. Ship to Millingville by freight at earliest possible period. Thanking you for your prompt methods in shipping the other, and wishing you abundant success, I am, Yo'srs very respectfully, SKELTON NAPIER.

Gibson, Miss., Oct. 29, 1900. Mr. J. R. Ratekin \& Son:-This year corn has been almost a failure here on account of too much rain, but the "Pride of Nishna" I obtained from you was planted on sand land and it made much more than any other corn in this vicinity, although it had but one plowing. It matured fully 30 days quicker and ahead of our native or common sorts.

The "Iowa silver Irine," white, was also planted on poor sandy land but it made fully twice as much as common native sorts planted in the same field and same kind of ground. Yours truly,

JOHN T. YODER.

Storey County, Iowa, Oct. 23, 1930. J. R. Ratekin \& Son:-The seed corn obtained from you last spring was good, never had a better stand. I planted $22 \mathrm{~d}$ to $26 \mathrm{th}$ of May on good land, and it is all yielding 75 to 80 bushels by weight, per acre, and from 10 to 15 bushels per acre more than native or ordinary sorts. "Pride of Nishna" is very deep grain, large ears, but dries out and is little earlier than "Silver Mine," white. Its all right.

$$
\text { Yours truly, }
$$

GraNt DEAL。

Loving words will cost but little, Journeying up the bill of life:

But they make the weak and weary Stronger, braver for the strife.

Do you count them only trifles?

What to earth are sun and rain?

Never was a kind word wasted,

Never was one said in vain. 
Mallet Creek, Medina County, Ohio, Oct. 10, 1900. Messrs. J. R. Ratekin \& Son.-Gentlemen:-The bushel of "Pride of Nishoa" seed corn I ordered from you last spring was received promptly and on time, but owing to extreme dry weather I did not plant it until June 9th, at which time I planted it on new sod ground that had been in pasture for several years, planting with an ordinary grain drill, rows thre feet apart. I got an excellentstand and just as the corn was coming through the ground I dragged it with : short toothed har row, cultivating it afterwards with a grasshopper cultivator, leaving the surface smcoth and absolutely clean. Owing to continued dry weather it grew very slow until about the first of Julv, when we had good rains, followed by hot weather, which made it fairly leap and jump until it was twelve feet righ, earing finely and in proportion to the stalks, fully maturing by the first of October. I have now husked it and

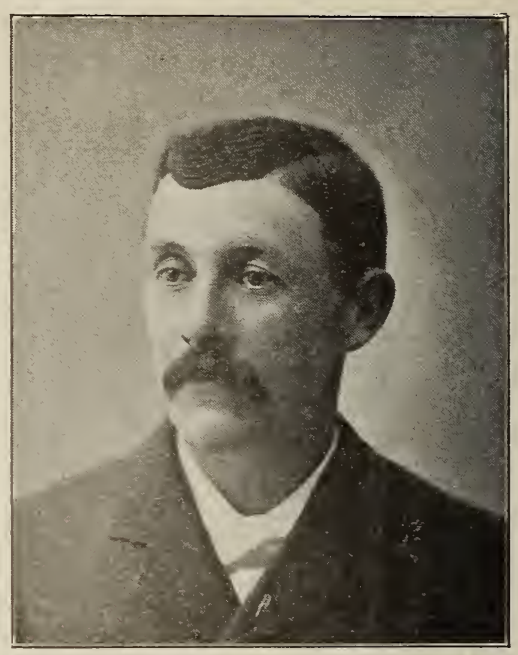

C. P. DICKERMAN. find it yielded considerably over 100 bushels per acre, just how much I can not now tell, but safely above the 100 bushel mark. For a large variety it has a wonderful deep grain and small cob, thus maturing in a rt markably short time. It is just the kind of corn I have long been looking and experimenting for. With best wishes for your success, I am,

Yours very truly,

C. P. DickERMAN,

Breeder of Yorkshire Swine, Jersey Cattle, Delain Sheep and Fancy Poultry.

Wood County, Ohio, Oct. 26, 1900. J. R. Ratekin \& Son.-Gentlemen:The "Pride of Nishna" seed corn we ordered and received from you last spring was planted May 22d, and made 836 heaping baskets from six acres, which is, as it ought to be, quite satisfactory to us. Every one who has seen this corn pronounces it the finest they have ever seen in this locality, and many want seed of it. The land on which it was grown has been farmed over fifty years.

Respectfully yours,

HALLADAY \& HAMHLTON.

Lake County, Ohio, Dec. 15, 1900. J. R. Ratekin \& Son, Shenandoah, Ia. -Dear Sirs:- The "Pride of Nishna" seed corn I bought from you last spring was, part of it, planted Nay 20th, on sandy loam soil. The stand was perfect; matured about sept 20th, yiélding about 100 bushels per acre. The remainder was planted May 28th, on clover sod, clay lo3m, yielding 120 bushels per acre; matured about Oct. $15 \mathrm{rh}$. The cultivation was thorough, and until about the time it begun to tassel and silk it looked like it would be somewhat later than our native sorts, but it got there even with it and proved much the biggest yielder of anything we have grown. Yours truly, J. SAWYER.

A very good way to get lots of fun out of life is to put lots of fun in it. Life is not built on the system of getting something for nothing. The man who sits at the pasture gate and waits for the cow to back up to him to be milked will be woefully disappointed, for she will never do it.

The fact that most people have two ears and one tongue ought to be a hint that twice as much listening should be done as talking. Some people reverse this order and talk twice and will not hear at all. 


\section{Winter Wheat Growing.}

In a considerable portion of the belt in which winter wheat is grown the farmer often finds himself between Scylla and Charybdis, winter killing threatening him on one side, and the visitation of the fly on the other. Very late planting will do much toward preventing the ravages of the fly, but it is likely to make the wheat plant go into the winter with so little growth and vigor that it cannot withstand the severities of the season. On the other hand, early planting of a hardy variety will in most instances prevent winter killing, but if there are any flies about that season the crop planted is pretty sure to be full of them, and by the time the wheat has suffered from the fall attack and that of the second brood of spring,'there remains lit tle or nothing to harvest. This being the situation that confornts the winter wheat grower in a considerable portion of the section devoted to the crop, it stands the planter in hand to try to steer between the t $\pi 0$ dangers and it can be done to a much greater extent than is usually the case.

It involves, in the tirst place, the early preparation of the ground and the reduction of it to a fine tilth. The soil should also be rich and strong so that when the crop is planted late it will make a strong, thrifty growth in a short time. The plowing should be done early and the cultivation thercafter until planting time should be frequent. If the field selected has been in clover, so much the bet,ter, for no crop that we know of equals clover as a preparation for winter wheat. The sowing of the wheat crop should $b$ ? late, aiter the fly has quit work, and taking one season with atother drilled wheat stands a better chance to make a good crop than that which is broadcasted. The amount of seed to be sown depends upon the character of the soil, thinner seeding being permissible on the strong ground with an increase on thinner, lighter soil. These lighter soils should be avoided, however, for with the late sowing necessary to escape the fly, they hardly ever prcduce a growth that will carry the stand throu= h the winter,and a strong fall growth is essential to a crop the follow!ng season, even with the var eties best adapted to the locality. This necessity for strong fall growth, coupled with the shortness of the time there is to make it if the fly is to be avoided, should emphasize in the mind of every planter the necessity for thorough preparation of the soil and for enriching it and manuring it thoroughly.

The choice of seed is important. Nebraska experiments teach us that the Turkish Red, the Big Frame and the Cornell are the only varieties of a large number that have been tested that are there reasonably certain to go through the winter without injury. At the Iowa Experiment Station a test of a number of years places the Turkish Red at the top of the list, the Bearded Fife, the Buda Pesth and the Bulgarian following close after it dnring the past season. The four varieties named, however, seem to us practically about the same. Bearded Fife is, we believe, the name under which Turkish Red is commonly sold in Minnesota, and all four of these varieties have a fine and rather stiff straw, a short beard and a white chaff. They seem to be the same variety grown under somewhat different conditions It is worth while to note, too, that there is reason to believe that where a hardy variety is sought that will pull through the winter and make a large crop the following season, it should be a bearded one. By this is not meant that all bearded wheats are hardy, but it does seem as though all the really hardy wheats are bearded. Where the conditions are such as require a hardy variety, all the tests in the West indicate that the planter cannot do better than select the Turkish Red, and in procuring seed it is better to get it from a locality north of where it is to be planted than south of it.-Iowa Homestead.

Who can gather wild roses sweet,

Or follow the fences for golden rod,

Or tramp through the clover the meadow over

And say to his neighbor, there is no God?

One day's plowing at the right time is better than a week when it will do no good. There is a time for everything. 


\section{Wheat Culture.}

The preparation of the ground for seeding to wheat should begin just as long before the time for sowing as possible. While there is some difference of opinion as to the depth to plow, personally we favor the shallow powing. Not over five inches, but this plowed well, no "cutting and covering," but each a properly turned furrow. It is well to drag down every evening all that has been plowed during the day. This assists in retaining moisture and also crushes the clods before they hecome dry and hard. After the plowing is completed the harrowing is begu $\mathrm{s}$ and then follows a rigid course of tillage with harrow and roller, or drag, which is continued at frequent intervals, after a rain when possible, until seeding time. A continuance of this pulverization insures a seed bed of fine soil, yet sufficiently compact, and the whole covered with the much desired dust mulch.

SEEDING TIME.-As to the proper time of seeding, every farmer must be governed largly by the conditions and location. For winter wheat, it should be sown early enough in the fall to give it a good start before the ground freezes. 'The Hes-ian fly, that has ruined thou-ands of acres of wheat, is supposed to be a common enemy of early sown wheat. While the results of the past year do not supply a complete verification of the fact, yet it is genarally conceded that wheat sown about September 20, for the 40 th parallel, and a few days earlier or later in places north or south of that latitude, is most likely to escape the ravages of the fly. But our experien ${ }^{\circ} e$ is that the most satisfactory way to eliminate this pest is by adnpting a system of rotation of the wheat crop with crops that are not capable of supporting the fly.

IN SEEDING, the most satisfactory results are obtained by usi g a drill. This is because a more equiable distribution is secured, and the sed covered more evenly, and it will ripen with practical uniformity. As to the depth,careful experiments have shown that the best yields have been secured from seed that was covered two inches.

THE SEED.-In the selection of the seed, too much care and good judgment cannot be exercised. As "like begets like" in the wheat field as well as elsewhere, nothing should be sown but clean, well ripened, well developed seed. In selecting wheat seed, the farmer should not only take in to consideration the soil and climatic conditions, and the best varieties selected; but the fanning mill should be frequently used, to thoroughly clean out both the noxious weed seeds and the degenerating light weight wneat, so that only the sound, plump kernels shall enter the drill.

HOW MUCH SEED.-As to the amount per acre, the advocates of thick and thin sowing are wedded to their favorite method, and are often extravagant in their claims. One thing is certain, however, and that is, if the seed is what it ought to be, less of large and vigorous seed will be required than would be of seed that was small and weak. Following on this, and in a properly prepared field, a bushel and a half per acre is sufficient.

One of the simplest methods of counter-acting deterioration is by repeated importations of seed from the regions whose natural conditions have produced the characteristics desired. On the other hand, plants and animals have in some instances been made to improve their desirable characteristics under conditions other than those in which nature produced them. Thus, Indian corn seems to have originated in Mexico; or at least to have come from Mexico to the lands in which it is chiefly produced. The superiority of northern corn over that of Mexico is such that none ever suggests a return to the native habitat of corn for seed

He gives the most who bravely lends a hand

To help his brother in the hour of need,

God keeps the record-He can understand,

And of our slightest service will take heed.

Provision is the foundation of hospitality, and thrift the fuel of magnifcence.-Sir P. Sidney. 


\section{Advice by a Wheat Grower.}

[The following is so practical and sensible that we here reproduce it for the practical value of points it touches and treats with.-J. R. R. \& Son.]

C. B. Hoffman, who for nearly twenty years has been in Dickinson county, east central Kansas, an extensive grower of wheat, besides interested largely in making flour for domestic and foreign markets, writes to secretary $F$. D. Coburn of the Kansas Board of Agriculture some very valuable and timely facts about wheats and wheat culture. He says in part:

Cause of Failure.-Neglecting to plow early, so that the soil will get thoroughly settled and compact, is perhaps the cause of more complete failures than almost any other. Sometimes it is impossible, on account of a lack of moisture, to plow the ground soon after harvest. Where this is the case, I would rather drill the wheat into unplowed stubble. if fairly free from weeds and insects, than plow late. Plowing can easily be finished by the first of August giving one and a half to two and a half months before seeding.

Time to Sow.-As to time of sowing, no definite rule can be given. All depends upon the condition of the soil and the presence of insects. If the field has been plowed in July, sow the last week in September or the first two weeks in October. If sowed earlier there is danger from insects, or from wheat getting too rank, if enough moisture, or sickly, if not enough moisture. The wheat plant should not be stunted too long by standing in the hot, dry autumn sun and wind. There should be a continuous growth from the time the seed drops into the ground until it goes into winter quarters; and then again from the time the sun's warm rays and the spring showers awaken it to life and growth until the heavy heads of well filled grain nod towards a rich and blessed harvest.

In western Kansas frequently the grain drops into dry soil, and remains in that condition until the spring rains cause it to sprout. Sometimes large crops are raised under these conditions for the plant has more vitality than if it had sprouted in the fall, but had not had sufficient moisture to root and stool. I have been unable to detect any material effect upon the grade and quality of the wheat which did not start to grow until spring, although continued spring sowing would no doubt deteriorate the quality and call for a change of seed more frequently.

The Seed.- The next great factors in the wheat culture are the kinds of wheat and the quality and purity of seed to be sown. Kansas grows both hard and soft winter wheat and a very limited quantity of a few varieties of spring wheat. Kansas is the only state that grows hard winter wheat in quantities worth mentioning. This is unique and deserves consideration. In fact, upon this I think depends the supremacy which Kansas holds over all other states, and will continue to hold in the production of wheat.

Quality of Seed.- "What kind of seed shall I sow?" is a question the importance of which is underrated by many farmers. Seed wheat should be pure-that is, of one variety. It should be well matured, full-grown, and free from smut or other parasitic or fungold growths. It should also be free from weed seeds, especially chess ("cheat"), which, being exceedingly hardy and prolific, will take the field if it bas half a chance, and is exceeding]y difficult to eradicate, when once it has infested a neighborhood. Poor, shriveled wheat, if sufficiently matured to sprout, will, under favorable conditions, produce a crop, but will surely cause the variety to "run out" in a very few years if continued sowing of inferior stuff is indulged in. A farmer should have a seed patch on which he grows wheat for seed. This he should give the best care; should plow deep and early, keep it free from weeds, use the best varieties and the purest seed, and from the products of this sow his larger fields.

Changing seed from one locality to another is desirable; even from one neighborhood to another; still better from distant parts; usually from northern localities to southern is better than from southern to more northern.

IT PAYS TO HAVE THE BEST.

Remember that our seed is carefully re-cleaned before sending out, and is absolutely free from rye, cheat and noxious weed seed, and never weighing less than 60, up to 65 lbs, struck-measure, to the bushel. All seed shipped as directed or on day order is received. 


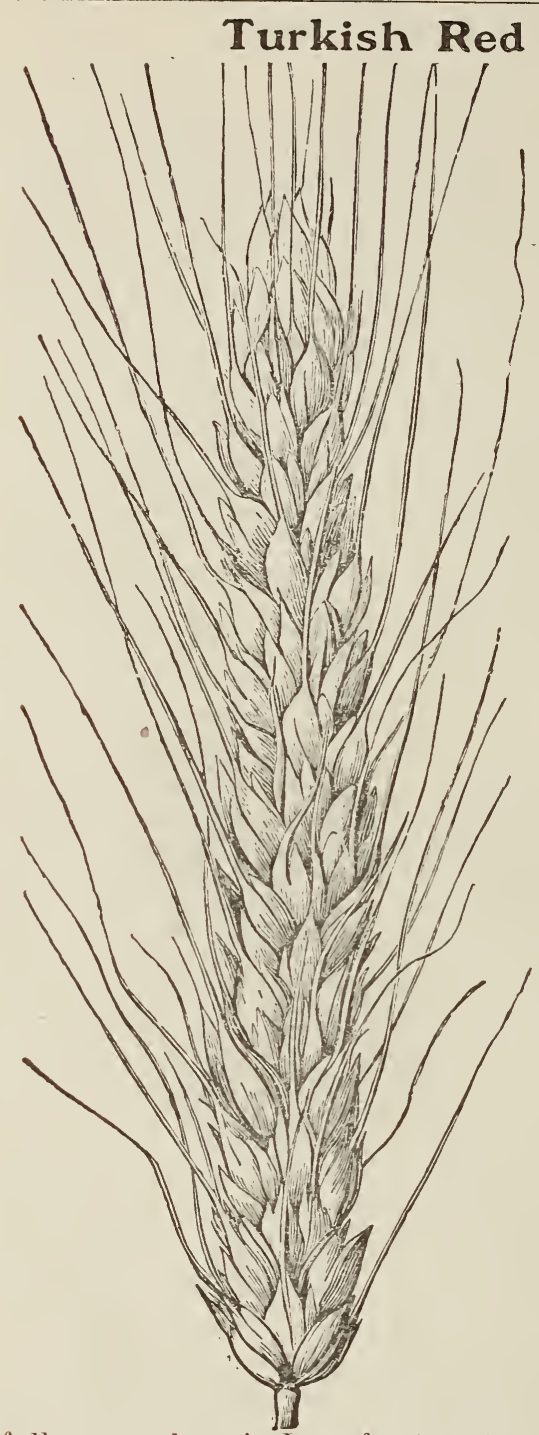
fowever it has not been advertised and has been but little known outside of portions of this state until within the past two or three years. Since, and within that time it has been thoroughly tried, tested and recommended by all the leading agricultural stations, not only of this state, but about all the leading agricultural colleges of the country, and through the medium of the agricultural press has been brought to the attention of wheat growing farmers; thus having become known it has created such a demand for seed of this wheat that most of the back date seedsmen begun to fall orer one another claiming to have been the original introducer of it, and in many cases advertised it as their "Novelty, Leader" etc., etc., at fabulous prices. So great has been the demand for this seed that we venture there has been thousands of bushels of seed wheat sold for Turkish Red that was not even akin to this wonderful variety. 


\section{Winter Wheat--Continued.}

In addition to the displayed cut and description of "Turkish Red" winter wheat on the preceding page, we here display another cut showing a bunch of this wheat from one grain and stalk. There is nothing in the wheat line that stools out like this variety, so far as we know. The heads are of good size and a great many of them to each root. The grains are plump, handsome and quite hard. The hull is reasonably thin and it makes a most excellent grade of flour. It is naturally a big yielder, a sure cropper and there is no danger of it freezing out. We believe there is no other variety in existence that will give as good satisfaction in every respect, that will produce as large a crop under ordinary conditions, that will make as much flour per bushel or weigh as heary struck measure as Turkish Red. Most of our stock sent out last fall, and we sent out many thousands of bushels of it, weighed over $6.5 \mathrm{lbs}$. struck measure per bushel.

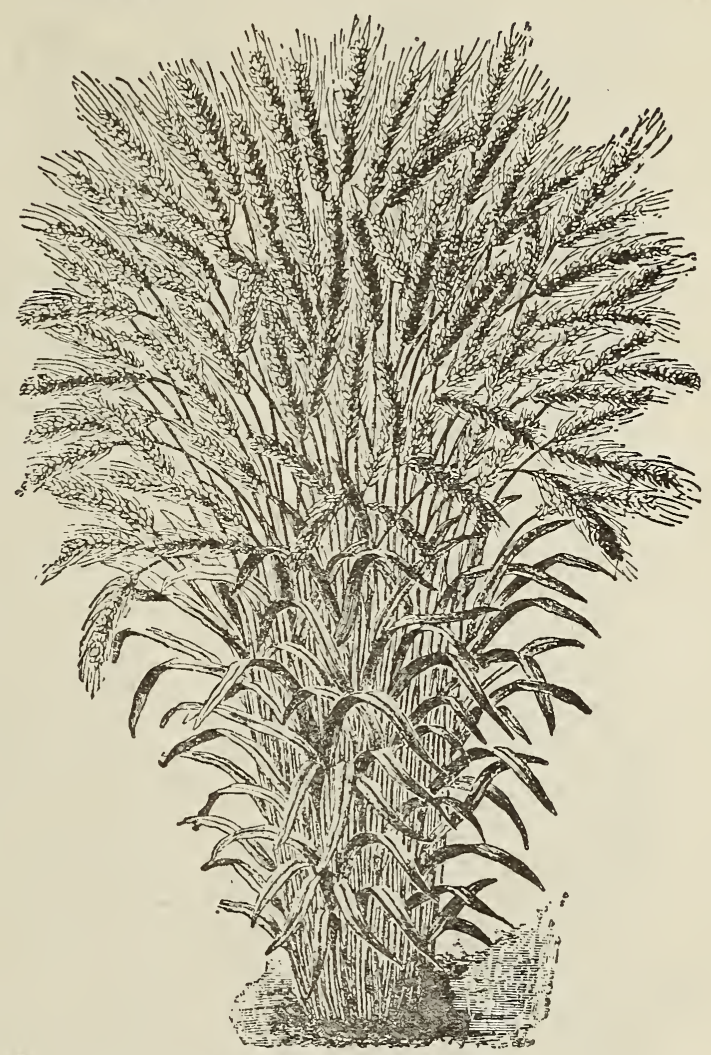

\section{Read State Experimental Reports Below.}

The Iowa State Experiment Station says: "Turkish Red winter wheat turned out exceptionally well this year (1900) going through the winter without the slightest injury and yielded 55 : 3410 bushels per acre. The milling quality is of the highest order. It ont yielded all the other 18 varieties of winter wheat tested with it, the average yield of the eight bald varieties in same test being only $17 \frac{1}{2}$ bushels per acre

At the Nebraska State Experiment Station in the fall of 1896 they sowed 37 varieties of winter wheat; it all winter killed except three; in 1898 over 100 varieties and only five survired the winter in good condition. In 1899 they sowed 42 varieties. In all of these tests the Turkish Red succeeded finely and is given first place on their list.

July 18, 1900.-For more than twenty years I was engaged in growing winter wheat in western Iowa, and bave grown Fultz, Michigan Amber, Clawson, Winter Fife, Mediterranean, and several other varieties, but discarded them all in favor of Turkish Red. It has yielded $31_{4}^{\frac{1}{4}}$ bushels per acre on my place and always deported itself well for me.-Geo. W. Franklin, Editor, Iowa Homestead.

PRICE.-Per $1 \mathrm{lb} .20 \mathrm{c}, 3 \mathrm{lbs}$. 50c, post paid by mail. We are unable to make prices so far in advance by bushel and large quantities, as there are so many things contingent on crops, prices, etc., but hope all who receive this catalogue, wanting to make a change to some other variety, will write us in season, and we will be pleased to quote prices at that time. 


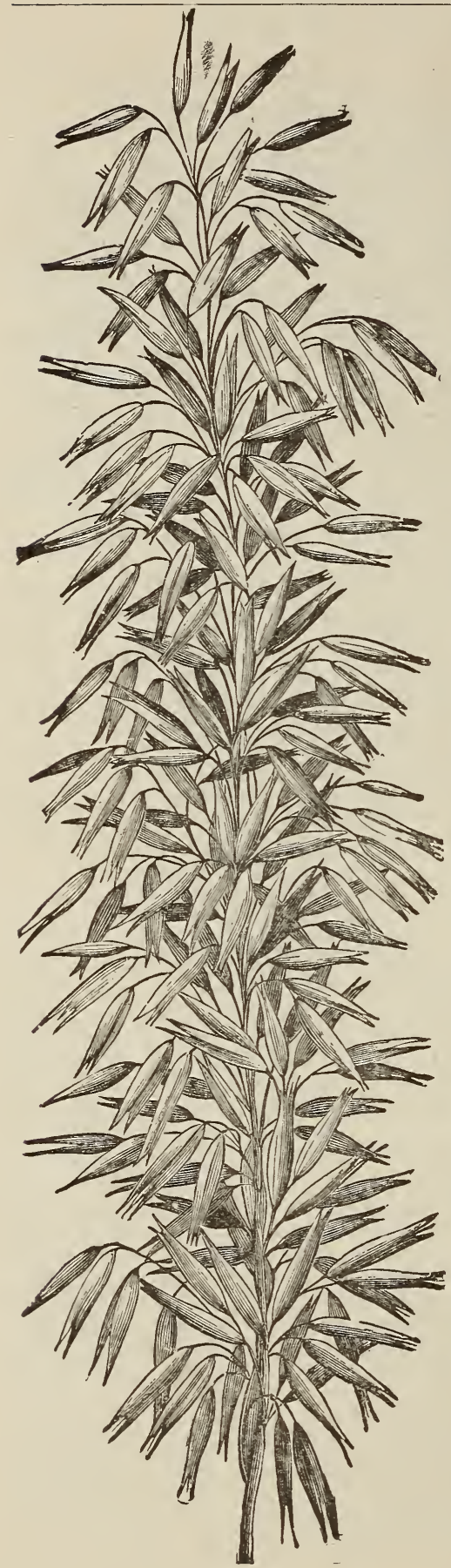

\section{Eultz Winter Wheat.}

Heretofore we have handled no other variety of winter wheat than "Turkish Red" believing there was but one best, and on account of this have not undertaken nor offered anything else, but we have found in the course of our corresponderce. inquiries and business, the Fultz to be the leading and favorite variety next to "Turkish Red," for varjous and special reasons, and there has been such a demaud for this excellent variety of wheat, that we have taken it up, and for the coming and next season trade will be in a position to furnish all our customers with seed of it from the finest and best strains grown, or to be found any where or by any other grower or seedsmen of this rountry. Price per 1 lb. 20c, 3 lbs. 50c, postpaid by mail. Dou't fail to write us for prices by bu. and quantity in seasoll.

\section{Early Champion Oats.}

Early Champion Oats, a new variety which was first introduced by the Iowa Seer Company in 1898, has given excellent satistaction everywhere among our customers who tried them last year. They gave the largest yield per acre of any variety in the test at the Iowa Agricultural College and are higbly recommended by them. These oats have comparatively short straw, mature a week or ten days earlier than other kinds thus largely escaping the liability of rust. Its greatest value lies in its especial adaption as a nurse crop to sow with grass seed as it does not stool as freely as some other sorts. 'They will not lodge on rich land. Henry Wallace, editor Wallace's Farmer, who is authority on clover and grasses says: "I would rather risk sowing seed with them than any other variety 1 know of." Price per pk. 25c, per bu. $60 \mathrm{c}, 10 \mathrm{bu}$. lots and more, $50 \mathrm{c}$.

Macon County. Ill., Nov. 15, 1900.

The two bushels of seed corn pur chased from rou last season is yielding 75 bushels per acre and has given entire satisfaction.

FRANK E. SAWYER.

Vernon County, Mo., Oct. 22, 1900.

J. R. Ratekin \& sion:-The "Iowa Silver Mine" seed corn I got from you last spring was planted the last days of A pril. It grew fine and did well, making more than twice the amount of corn that I raised on same ground last year.

Yours truly, C. C. TAYLOR. 


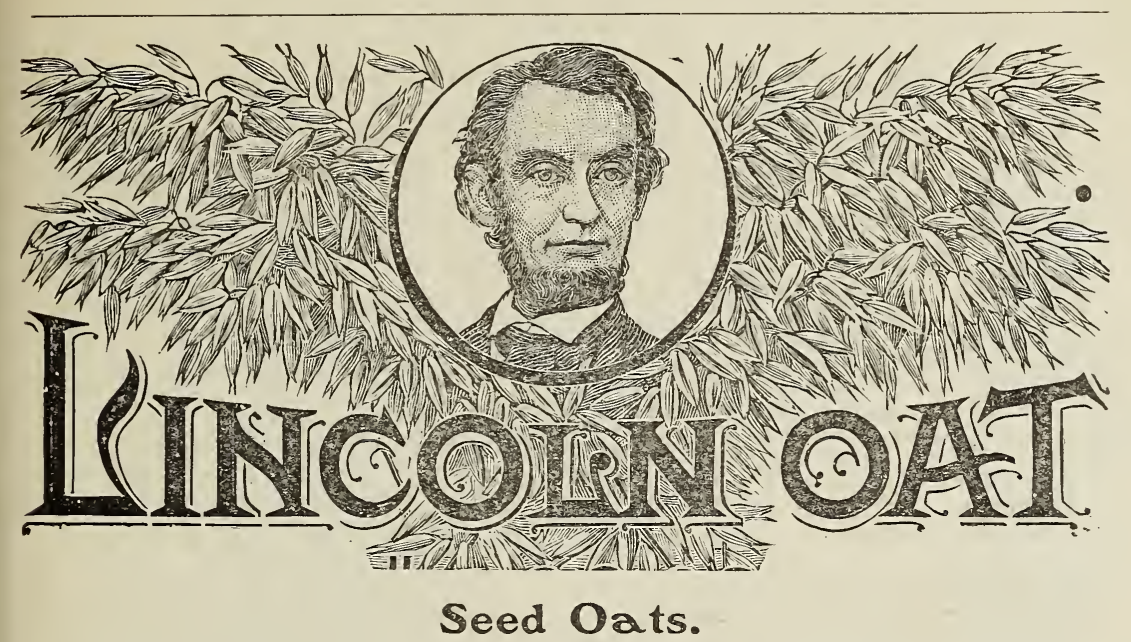

Lincoln Oats. - When these oats were introduced for the first time by the Iowa Seed Company in 1899 they had never been tested in this state, but had done so exceptionly well in Minnesota, that that seed company offered seven prizes, amounting to $\$ 500$, for the largest crops grown from one bushel of seed sown. The first award going to a man who grew $17 t$ bushels from one bushel of seed sown, and the average of the seven successful competitors was 116 bushels each. What is claimed for the Lincoln oats is that it is a very heavy yielder, is comparatively early, has proven itself to be entirely rust proof, and stands up exceptionally well. On account of its soft nib, heavy meat and thin hull, it is unsurpassed for feeding and for making into oat meal. Our stock was grown from headquarters stock and are the pure variety. Price by freight, bags free, 65c per bushel. 10 bushel or more $60 \mathrm{c}$ per bushel.

\section{Sowing Rape with Oats,}

By seeding with Early Champion Oats at the usual time, then after oats are up three to four inches high, sow 3 to 5 lbs of Dwarf Essex Rape per acre, and if ground is not wet, turn in sheep or other stock for a week, to tramp it in. The stock will eat down the oats but this will do them good, and will do no harm to the crop. After the oats are harvested the rape will soon be from one to three feet high and it will furnish an almost untold amount of pasture the balance of the fall, and there is nothing better for sheep, horses, cattle and hogs. Let every farmer try this once, and our word for it, they will ever repeat it afterwards.-J. R. R. \& Son.

THE IOWA HOMESTEAD says: "Among the leading forage crops enumerated, Dwarf Essex Rape should unquestionably be crowned the KING. In 1890 , it is claimed by those who ought to know, that less than 500 lbs of rape seed were sold for forage uses in all the United States. The present season, 1900, there are good reasons for believing that more than 5,000,000 sheep and lambs have been fattened on rape. This wonderful plant may be sown any time between the dawn of spring and the closing in of winter, providing that it can have eight weeks in which to grcw, and the soil is moist enough to germinate the seed."

"Couldn't I be squeezed in there some how?" asked the pretty girl as she vainly sought entrance to the crowded car.

"If you can get in, I have one arm free," exclaimed a young man in the center of the car.

And the conductor" ran six "go ahead" signals on the fare register. 


\section{Velvet Chaff or Blue Stem Wheat.}

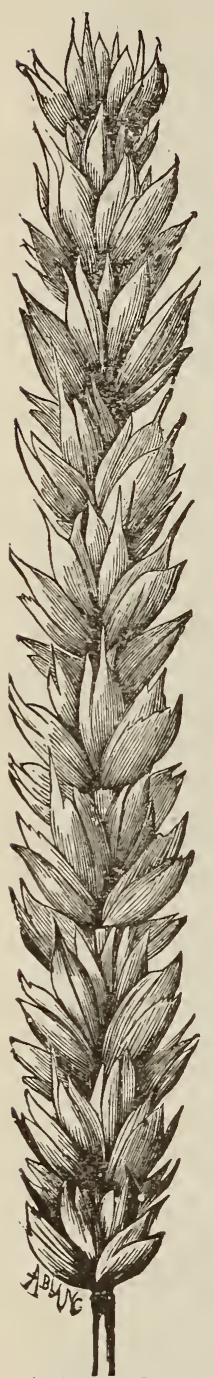

The Velvet Chaff or Minnesota Blue Stem spring wheat does the best throughout the spring wheat growing country. It is a remarkable semi-hard spring wheat, yielding large crops and is free from rust. Our millers here pay more for it than any other sort, It is fully equal to the old fife wheat and yields a very much larger crop. It is now the main crop in the northwestern states and the great milling firms use it for their highest grade flour, and it has been the most reliable variety one year with another, yielding a good crop where other sorts fail. Our seed this year is very fine and we are sure it will please our customers. It is recleaned and grained and you will find it absolutely free and clean, clear of all oats and other noxious seed. Price per pound 20c, 3 lbs. 50c, By freight, bags free aboard the cars here, $\$ 1.10$ per bushel.

\section{Winter Wheat.}

From Iowa Homestead.]

Much interest is manifested this winter in winter wheat owing to the immense yield this year and the reports just published by the Iowa state Experiment Station, showing that the crop has proved so profitable for several years past. It there is one point in regard to winter wheat culture which seems to be well settled by exhaustive trial, is that the variety of seed selected for sowing must be chosen with a due regard for the soil and climatic conditions under which it is to be sown. Another point seems to be equally well ascertained, and that is that in. the wheat belt of the middle West no variety endures the winter so well or produces so large a yield as the Turkish Red Winrer wheat. At the Iowa Experiment Station this year the yield of Turkish Red was a little over filty-five bushels per acre, and the only varieties that approached it were three others that were practically the same thing but grown in other localities and there known under different names. The results of this year at the Iowa Experiment Station, too are in harmony with those of previous years when a large number of varieties, including the 'Turkish Red, were grown. Every year the Turkish stood at the head of the list. Similar results were also secured during several years' test at the Nebraska Experiment Station, and in Kansas and Missouri, too, the Turkish Red is a prime favorite. When it is considered that the average crop of wheat in the United States for the past ten years has been but about 12 bushels per acre, you will readily see what this wonderful increase would mean. Messis. J. R. Ratekin \& Son, the Nishna Valley seedsmen, at Shenandoah, Iowa, have been fortunate enough to grow this year a large amount of this very valuable variety, and are offering it to the farmers of the middle West on terms that make its purchase one of the most profitable investments that those who mean to grow winter wheat could possibly make. The reputation of Messrs. Ratekin \& Son, is thoroughly well established and the thousands of farmers all over the country who have purchased the admirable varieties of seed corn with which their names have been connected will need no assurance from us of their reliability or of the fact that they will receive fair treatment in any dealings that may be had with them. Write to Messrs. Ratekin \& Son for such supplies of the Turkish winter wheat as may be needed.

It is not childish to consider the child crop. It is one of the best crops grown although somewhat neglected. Some men get childish when old. 


\section{Evergreen Sweet Fodder Corn.}

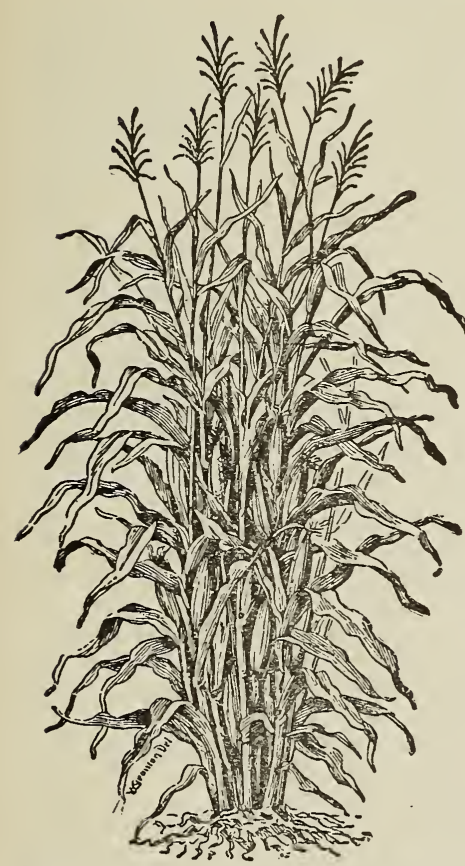

Evergreen Sweet Corn, we say unqualifiedly is one of the most valuable fodder plants in existence and all stock farmers. whether on the large or small scale. should devote from one to ten acres of ground to the cultivation of this superlative crop. The stalks are sweet, rich, juicy, tender and very nutritious. The leaves, which are very numerous, are lárge. broad, succulent and greatly relished by all kinds of stockit being greatly and far superior in every respect to other sorts of corn. On strong, rich soil it will grow 10 to 12 feet high and produce an incredible amount of fodder which, when cured, is equal to hay and relished by all kinds of stock equal to the very best clover hay. We have here one of the largest, if not the largest canning factories to be found in this or any other state where sweet corn is canned, and owing to the excellency and wonderful yield of roasting ears, it is planted to the exclusion of all other varieties. The canning company paying four dollars per ton for the corn in husk at canning time, it makes a very protitable crop even at this price, often yielding five tons of roasting ears per acre or $\$ 20$ per acre for the product, besides the stock fields alone often sell at two dollars per acre after all the corn is gathered. when stalk fields, where common field corn was grown, sell for 40 and $50 \mathrm{c}$ per acre. stock love it so well that they will eat the dry stalks so clean there is not a vestige left that you would know the ground produced a crop of corn. This variety is decidedly and by all odds the largest and greatest producer grown. We measured ears of this which were selected for our seed this year that measured 12 inches in length, and you can always rely upon every stalk producing at least one good ear, and fully forty to fifty per cent having two and even as many as three good ears on them. It will bear planting a full half thicker or even more, than ordinary field corn, but it is rather more sensitive to cold, wet weather about growing and giving a good stand and should not be planted before the prime time for planting other corn, and then only when the ground is in good order. If planted exclusively for fodder and forage, sow in drills or broadcast, as you would sow wheat or oats at the rate of two bushels per acre. We cannot too strongly urge every farmer to try a few acres, the coming season. It will not disappoint your best wishes and expectations, and every thing will smile that you feed it to, from the family table to the pig pen. Price per 1 lb. $20 \mathrm{c} ., 3 \mathrm{lbs}$. 50c, per bushel $\$ 1.75$,

The Difficulty - "I am quite willing to admit that I should like to marry." "Go ahead. Can't you find a wife?" "Wives enough; but no suitable fatherin-law." 


\section{Dwarf Essex Rape.}

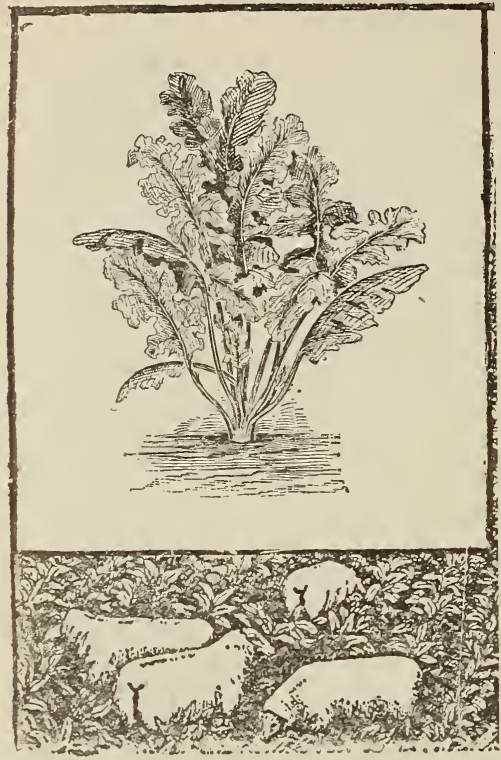

Of comparatively recent introduction in this country, but has proved to be the most valuable forage plant in existence for many sections of the country. It is easily grown everywhere, can be sown early with a grain crop, but is usually sown in June o.I July in a field with corn or potatoes for summer or fall pasture. It produces a wonderful amount of feed, one acre being sufficient for 30 to 40 sheep and lambs for two months, and they gain flesh so rapidly that they soon "weigh like lead." While it is the ideal food for sheep, still it is of equal value for hogs and cattle, as they are very fond of it, and it is extremely cheap, having yie'ded $9 \frac{3}{4}$ tons of fodder from $\frac{1}{2}$ acre. It is well to make several sowings during the season, so as to have it from early until late. If soil is rich and clean, sow broadcast, but on most land it will pay to sow in drills and cultivate once or twice to keep down weeds. Dwarf Essex Rape is well adapted for a catch crop where other crops have from any reason failed as it makes most of its growth late in the season. Can be sown in stubble after oats, wheat, etc., and makes a fine fall pasture. Our seed is the best imported and cannot be surpassed. P'er pound, 30c: 3 lbs., 75c, postpaid. By freight, 5 lbs, 60c; 10 lbs. $\$ 1.00,25$ lbs. $\$ 2.00,100 \mathrm{lbs}, \$ i .00$. T. J. Kegley, of 1 mes, Iowa, says: "I have been glowing INarf Essex Rape for the last four years and find it a very satisfactory food for sheep, hogs. and cattle. I would not think of farming without a good acreage of it. I plant between potato rows or sow with rye or vats."

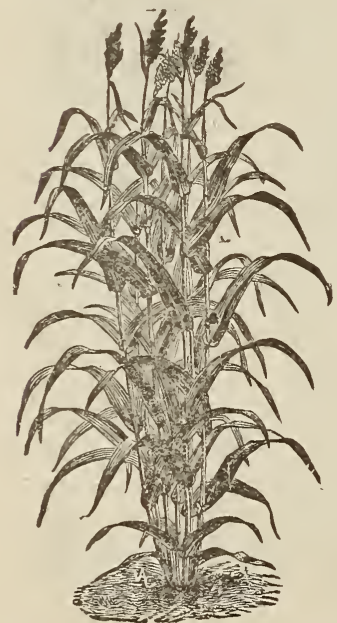

\section{Early Amber Cane.}

1 mber Cane in recent years has attracted great attention as food for live stock, and is now recognized for its great value and its adaptability as sucli. Its great merit as a food has become known and is here to stay, being very genelally known and appreciated. The demand is increasing more and more every year and each year ten fold more than the last. It is profital)ly grown fverywhere from Manitoba to Mexico on any good corn land and is not effected by drouth as other crops are, but produces wonderful forage crops rain or shine. As a foddder plant it is the most productive and economi(al plant in existence, and of the very best quality, Being sweet, tender and nutritious it is greedily eaten by cattle, horses and hogs. Dairymen find that cows give more and richer milk from its use than any other food, and it is claimed by some that as high as twenty-five, thirty and eren tifty tons of the green fodder have been grown from one acre. It can be cut several times during the season if not allowed to get too large or high, and make good, sweet hay. Sow $100 \mathrm{lbs}$. per acre for best results. Price per 1 lb postpaid by mail $20 \mathrm{c} ; 3$ lbs 50c, 100 lbs by freight, at expense of purchaser, $\$ 2.00,500 \mathrm{lbs} \$ 9.00$. 


\section{Kentucky Blue Grass.}

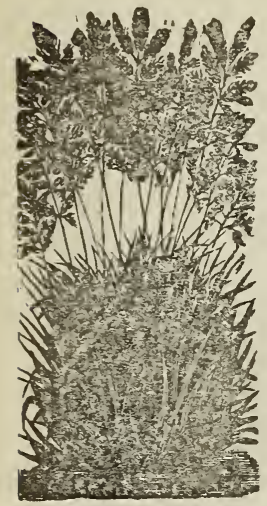

kentucky Blue Grass is exceedingly popular everywhere, not only for lawn but for pasture as well. It is very productive. nutritious and unusually early in spring, furnishing delic:ous food for all kinds of stock. It is not easily effected by drouth, and frost nor cold effects the crop on the ground when wiater season comes: in fact stock will graze on it during the entire winter, and horises will paw through the snow to get it in wiater time. It is suited to almost any climate and soil in the waion, and for pactical uses for pasture invaluable. Our seed is all new crop of the best grade, from the lest Kentucky glowers: Fancy ceaned. Sow 14 lbs. per acre for pastre or (i) to 100 ils. for sure quick and immediate lawns. Per lb, 3.c; 3 llis, 80e, postpaid by mail. Per bu.. 14 lbs., by freight or express, at tuyers expense, \$1.75.

\section{Timothy.}

Timothy grass stands at the head of all other tame grasies for hay, ald stands superior to them all. Wie are located in a fine country for Bluegrass, Clorer and Timothy and can supply the very best quality of seed. Iowa grows more timothy seed than any oiher state or part of the world. Timothy scerl, howerer, is very scarce this ycar. and consequently much higher than for a number of rears past. Price by mail postpaid, per 1b.. 20c: 3 lbs, 50c. per bu. (45 lbs) bag free, by freight or express, at purchasers expense. Write for prices,

\section{German Millet.}

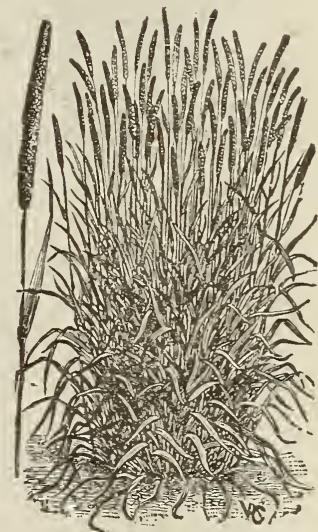

German Millet is much better than common millet, as it will produce double the crop. but at this time we are unable to make pricess as the price on millet seed is very fluctuating, but will be pleased to quote prices at any time when seed is wanted.

\section{New Siberian Millet.}

This is a new and distinct variety, having bright red seed, produces a fine crop of hay about two weeks earlier than German Millet, is very leafy and of excellent quality. Sow 25 lbs per acre. By mail per 1b. $20 \mathrm{c}$ : 3 1bs, 50 . For bushel prices write us.

\section{Kaffer Corn.}

Kaffer Corn is an excellent plant for fodder, yie'ding two crops during a season. It grows from four to six feet high. making a straight, uprisht growth. It has a stalky stem with numerous wide leaves and heary foliage. The stalks keep green and brittle, not hardenng like other varieties of the sorghum plant. making an excellent fodder, either green or dried which is highly relished by cattle. horses and mules. The seed crop is also very heary sometimes yielding from 50 to 60 bushels to the acre. For fodder, sow 25 to 50 lbs either broadcast or in drills. Per $1 \mathrm{lb} .20 \mathrm{c}, 3$ lbs $50 \mathrm{c}$, by freight per $\frac{1}{2}$ bu. $\$ 1$. per one bu. or more $\$ 1.25$. 


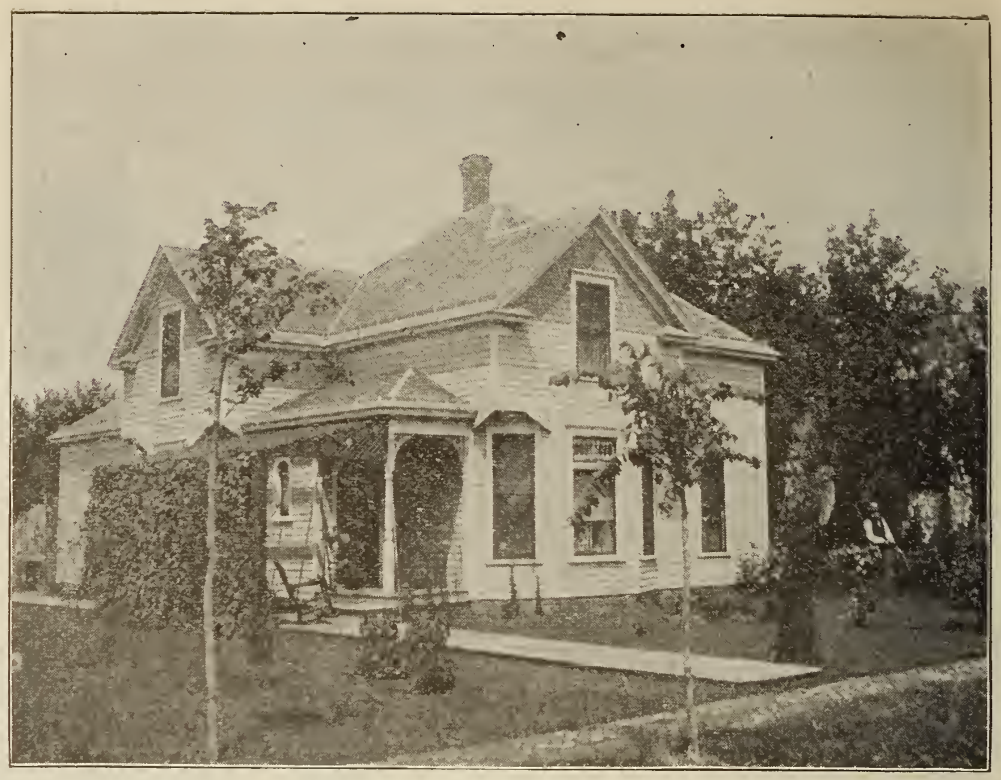

HOME OF J. R. RATEKIN. - LIWN FROM OUR SEED FIRST YEAR.

\section{THE LAWN.}

Thank God for grass! No other glory vies

With the refreshing glory of the grass:

Not e'en the blue of the o'erbending skies.

Nor fading splendors when the daylight dies,

Can this sweet smile of living green surpass.

I nice relrety lawn adds more to the beauty of a place than any other adormment, ald even the liumblest home may be made attractive with snch smrourdings, while without a good lawn even the finest flowering plants and clegant arranged bed seem insignificant: How important it is, then, to plan for the best lawn obtainable. I o not spend money in sodding a lawn, for it is expensive and is seldom satisfactory. When sod is cut from the roadside or some out of the way pasture, it is poor in quality and full of weeds, and when unevenly laid produces a rough surface which disfigures the lawn. It costs much less to sow the seed and the lawn is far better.

\section{Evergreen Mixed Lawn Grass Seed.}

This is a mixture of the best varieties of grass seeds suited for growing together in central and northern states, and will make a beautiful solt, velrety lawn and as handsome a green as an emerald, and is formed of grasses which keep green from early spring all through the hot, diy summer weather until late in the fall. It comes up quickly (about two weeks) after seed is sown, and after once up it soon spreads to cover the ground and is ready for lawn mower in six to eight weeks. It roots deeply on any soil and forms a dense, thick turf with no tendency to grow in turts or clumps. It is permanent, maintaining its beauty for a lifetime, although it is a good plan to give any lawn a top seeding once in every three to five years. 'This mixture is from new crop, recleaned pure seeds of the best varieties, well suited for even and permanent growth, as good as money can buy. It cannot be evt celled for producing a rich, velvety lawn of beautiful dark green co? Price per qt. (will sow 300 square feet) 2.c, 4 qts. 85c, postpaid. By fregl. per bushel of $15 \mathrm{lbs}$., $\$ 2.75,50 \mathrm{lbs}, \$ 8.00,100 \mathrm{lbs}$. (will sow one acre) $\$ 15.00$. 


\section{Freight and Freight Rates.}

We have obtained through our several railroad agents here, ireight rates to 38 leading points which will serve as a guide to approximate the freight rate from here to your nearest railroad station. The prices given for seeds of all kinds include bags free aboard the cars here, but we do not pay freight in any case, except the money is sent with the order to prepay it here, which is necessary if you have no railroad agent at your station, as railroad companies will not accept goods for such stations except they are first prepaid at starting point. In such cases (where there is no agent) the parties ordering should always send money to prepay freight, and if more is sent than it costs it will always be returned to the sender.

In all cases where you want seed of any kind, whatever, in pound quantities we can pack and send them safely and securely in a bag of corn, and will be pleased to do so, and you can therefore deduct eight cents per pound, from the pound prices, the amount of postage it would cost us if sent by mail.

Remember that express rates are about four times as much as freight rates, therefore don't nezlect to order early and in plenty of time.

Remember always, that we ship seed same day order is received, and send shipping bill at same time, if to be shipped any time in future we always acknowledge order by first mail.

$$
\text { Very respectfully, }
$$

J. R. RATEKIN \& SON.

Shenandoah, Iowa, Jan. 3, 1901.

Rates on Seed Corn, in bags, per 100 lbs., at this date, from Shenandoah, Iowa:

Atchison, Kansas.........22c $\mid$ Memphis, Tennessee......42c Atlanta, Georgia..........94c Macon, Georgia ...........94c Burlington, Iowa.........24c Mobile, Alabama..........88c Buffalo, New York.......47c Nashville, Tennessee.......57c Chicago, Illinois..........32c New Orleans, Louisiana......67c Cincinnati, Ohio..........42c Ottumwa, Iowa...........11c Council Bluffs, Iowa........ 9c Omaha, Nebraska.............11c Cedar Rapids, Iowa .... ....39c Peoria, Illinois .............. 29c Clinton, Iowa ...........43c Decatur, Illinois...........30

Ta venport, Iowa........27c

oit, Michigan........45c Evansville, Indiana.........42c Indianapolis, Indiana......41c Kansas City, Missouri......20c Lincoln, Nebraska.........24c Louisville, Kentucky.......42c Little Rock, Arkansas......75c Quincy, Illinois...............27c Richmond, Virginia...........59c Springfield, Illinois..........29c Springfield, Missouri.........37c Sioux City, Iowa............31c St. Louis, Missouri..........27c Terra Haute, Indiana..........39c Texarkana, Arkansas..........79e Topeka, Kansas . ...........32c Vicksburg, Mississippi........67c Wichita, Kansas ............53c

Buy your Seed Corn from the grower. Then you will know where it was grown. 


\section{THE NISHNABOTONA VALLEY.}

\section{The Greatest Corn Growing District in the Greatest Corn State in the United States.}

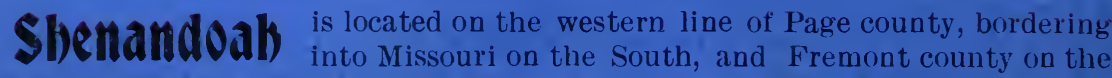
West, the extreme Southwestern county in Iowa, and is in the "Great Nishnabotona River Valley." The city has 4,000 inhabitants, is on the main line of the Omaha and St. Louis division of the great Wabash Railroad, and on the Omaha, Kansas City \& Eastern, known here as the "Quincy Route;" on the Red Oak and Lincoln line of the C, B. \& Q., "Burlington System," thirty-one mlles east of Nebraska City, and also on the line of the Keokuk \& Western, which has recently been absorbed by the "Burlington System," and which road has likewise swallowed the Humeston \& Shenandoah Railroad, thus giving Shenandoah the benefit of four trunk lines, and tapping about all the through lines centering into Omaha, Kansas City, Chicago and St. Louis and other intermediate points.

Dace Oolnty and the "Great Nishnabotona Valley" have long ag" age Uully become famous throughout the United States, if not the world, for the Corn it grows. Its location, climate and soil all unite and combine to the most perfect growth and maturity of the finest corn the world can produce. As far back as 1880 , and before all its broad prairies were broken and brought under the magic hand of man, and the plow, the county of Page, $22 \times 24$ miles square, prodused the enormous and unprecedented yield of Six Millious, 'Two Hundred Thousand, Six Hundred and I hirtytwo Bushels of Indian Corn, as shown by the United States census report: over three hundred and twenty bushels of corn for each inhabitant-man woman and child resident in the county at that time. This is equal to the combined corn product, the same year, of the following states: Maine, New Hampshire, Massachusetts, Rhode Island and Connecticut, and in addition equal to more than any one of ten other states.

By the above it will be seen that Page county, Iowa, has made an unparalled record, area compared, with any other County in the United States, or same amount of territory covered in the WIDE WORLI, and is justly proud of the name and banner she bears, "The Kingdom of Page that grows the Greatest, Most and Best Corn in the world."

See Inside Cover Page for Freight Rates. 